\title{
Alkaloids and styryllactones from Goniothalamus cheliensis
}

\author{
Wuttichai Jaidee \\ Mae Fah Luang University \\ Raymond J. Andersen \\ University of British Columbia \\ Brian O. Patrick \\ University of British Columbia \\ Stephen G. Pyne \\ University of Wollongong, spyne@uow.edu.au \\ Chatchai Muanprasat \\ Mahidol University \\ See next page for additional authors
}

\section{Publication Details}

Jaidee, W., Andersen, R. J., Patrick, B. O., Pyne, S. G., Muanprasat, C., Borwornpinyo, S. \& Laphookhieo, S. (2019). Alkaloids and styryllactones from Goniothalamus cheliensis. Phytochemistry, 157 8-20.

Research Online is the open access institutional repository for the University of Wollongong. For further information contact the UOW Library: research-pubs@uow.edu.au 


\title{
Alkaloids and styryllactones from Goniothalamus cheliensis
}

\begin{abstract}
Eight previously undescribed compounds, including four alkaloids and five styryllactones together with 36 known compounds were isolated from the twig and leaf extracts of Goniothalamus cheliensis. Their structures were elucidated by extensive analysis of their spectroscopic data. The absolute configuration of $(-)$ $(4 \mathrm{~S}, 5 \mathrm{~S}, 6 \mathrm{R}, 7 \mathrm{~S}, 8 \mathrm{~S})$-goniochelienlactone and (-)-(4S,5S,6R,7S,8S)-7-acetylgoniochelienlactone were established from single crystal $\mathrm{X}$-ray analysis using $\mathrm{Cu} \mathrm{Ka}$ radiation. The absolute configurations of the other related compounds were identified by comparisons of their ECD spectra with those of related known compounds. Most of the isolated compounds were evaluated for their cytotoxicities against human colorectal cancer cells (HCT-116). Griffithazanone A was the most potent with an IC50 value of $2.39 \mu \mathrm{M}$.
\end{abstract}

\section{Publication Details}

Jaidee, W., Andersen, R. J., Patrick, B. O., Pyne, S. G., Muanprasat, C., Borwornpinyo, S. \& Laphookhieo, S. (2019). Alkaloids and styryllactones from Goniothalamus cheliensis. Phytochemistry, 157 8-20.

\section{Authors}

Wuttichai Jaidee, Raymond J. Andersen, Brian O. Patrick, Stephen G. Pyne, Chatchai Muanprasat, Suparerk Borwornpinyo, and Surat Laphookhieo 


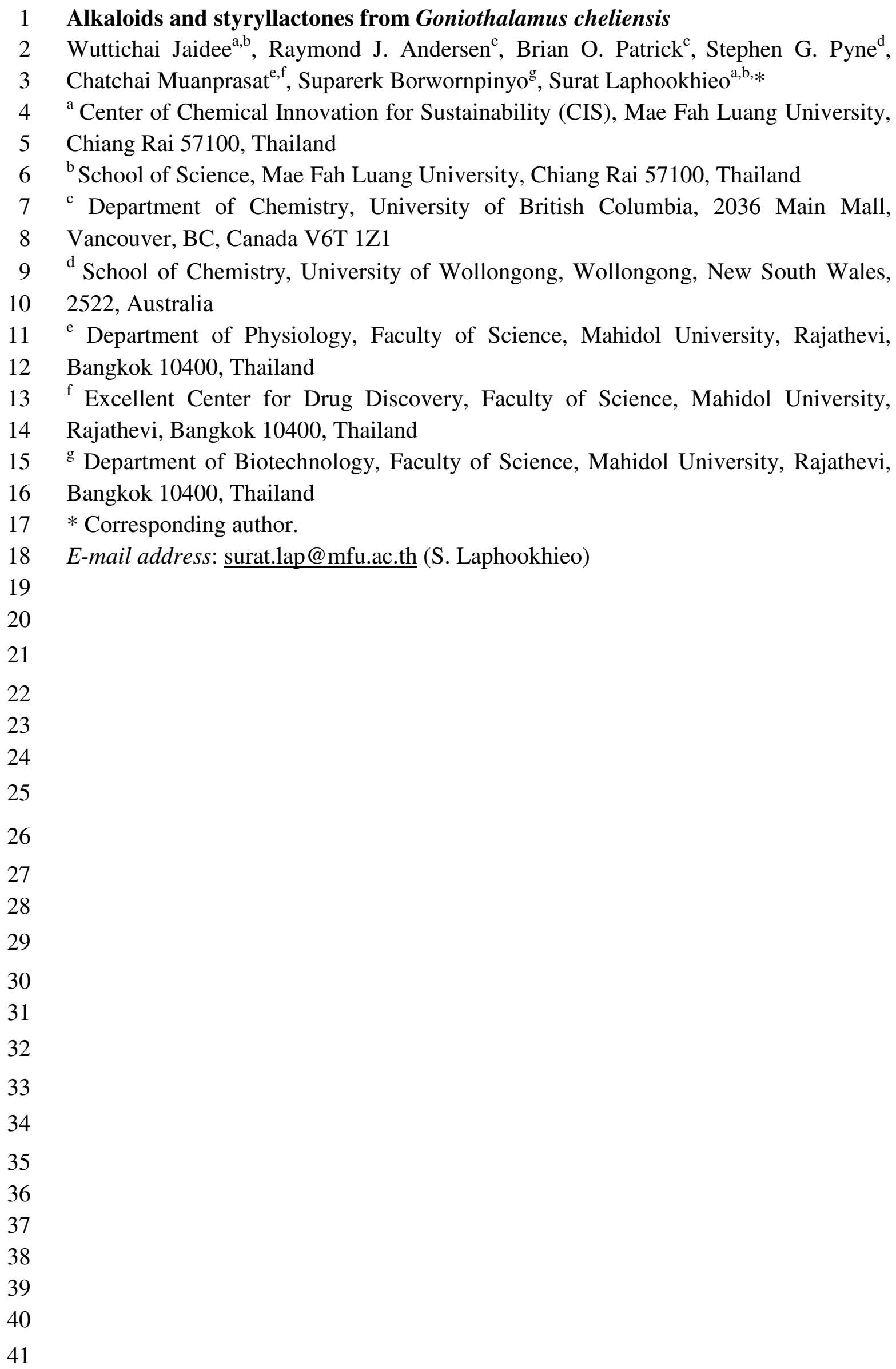




\section{ABSTRACT}

Eight previously undescribed compounds, including four alkaloids and five styryllactones together with 36 known compounds were isolated from the twig and leaf extracts of Goniothalamus cheliensis. Their structures were elucidated by extensive analysis of their spectroscopic data. The absolute configuration of (-)$(4 S, 5 S, 6 R, 7 S, 8 S)$-goniochelienlactone and (-)-(4S,5S,6R,7S,8S)-7acetylgoniochelienlactone were established from single crystal X-ray analysis using $\mathrm{Cu} \mathrm{K} \alpha$ radiation. The absolute configurations of the other related compounds were identified by comparisons of their ECD spectra with those of related known compounds. Most of the isolated compounds were evaluated for their cytotoxicities against human colorectal cancer cells (HCT-116). Griffithazanone A was the most potent with an $\mathrm{IC}_{50}$ value of $2.39 \mu \mathrm{M}$.

Keywords: Goniothalamus cheliensis, Annonaceae, Alkaloids, Styryllactones

(1)

(1)

(1)

(1)

(1)




\section{Introduction}

Goniothalamus is the one of the largest genera of the family Annonaceae. It is distributed throughout the world and is found predominately in Southeast Asia (Duc et al., 2016). This genus includes about 160 species, of which 25 are found in Thailand (Saunders et al., 2008). Some species have been used as traditional medicines for the treatment of fever (Surivet and Vatèle, 1999), scabies (Heyne, 1950), edema, rheumatism (Jiang et al., 2011), tympanites (Quismbing, 1951), and typhoid fever (Efdi et al., 2010). Goniothalamus cheliensis $\mathrm{Hu}$ is a large green tree which is distributed throughout the forested slopes at $1500 \mathrm{~m}$, in South Yunnan, China (Saunders et al., 2008). This plant is found in the Northern parts of Thailand, especially in Chiang Rai and Nan Provinces. Previous phytochemical investigations of $G$. cheliensis, resulted in the isolation and identification of various types of compounds, including styryllactones (Jiang et al., 2011; Wang et al., 2002; Zhu et al., 2012, Duc et al., 2016; Wang et al., 2003, Si et al., 2002), alkaloids (Jiang et al., 2008; Duc et al., 2016), flavonoids (Wang et al., 2003, Sun et al., 2014), and acetogenins (Duc et al., 2016). Many of these isolated compounds exhibited a variety of biological activities such as antiproliferative (Sun et al., 2014), antifungal (Duc et al., 2016), antimalarial (Duc et al., 2016) and cytotoxic activities (Wang et al., 2002; Zhu et al., 2012). In this study, we describe the isolation and identification of eight previously undescribed compounds (1-3 and 5-9) and 36 known compounds (4 and 10-44) (Fig. 1) from the twig and leaf extracts of G. cheliensis collected from Doi Tung, Chiang Rai Province, Thailand. Their cytotoxicities against the colon cancer cell line HCT-116 are also reported.

\section{Results and Discussion}

The acetone extracts of the leaves and twigs of G. cheliensis were individually subjected to separation by silica gel and Sephadex LH-20 column chromatography (CC) followed by semipreparative RP-HPLC to afford eight previously undescribed compounds (1-3 and 5-9) and 36 known compounds (4 and 10-44). The known compounds were identified as 3-methyl-1H-benz[f]indole-4,9-dione (4) (Efdi et al., 2010), (-)-goniobutenolide B (10) (Xu et al., 1994), 7-epi-(-)-goniobutenolide B (11) (Popsavin et al., 2012), (+)-goniodiol (12) (Fang et al., 1991), goniodiol-8monoacetate (13) (Wu et al., 1992), (+)-7-O-acetylgoniodiol (14) (Kampong et al., 2013), 8-acetoxy goniofufurone (15) (Zhang et al., 1998), isoaltholactone (16) (Colegate et al., 1990), (+)-glaberide I (17) (Wu et al., 2013), (-)-glaberide I (18) (Chang et al., 2015), (+)-syringaresinol (19) (Rahman et al., 2007; Yamauchi et al., 2015), (+)-medioresinol (20) (Nakasone et al., 1996; Yamauchi et al., 2015), (+)episyringaresinol (21) (Chen et al., 1998), (-)-syringaresinol (22) (Rahman et al., 2007; Yamauchi et al., 2015), (-)-episyringaresinol (23) (Lui et al., 2015), (-)pinoresinol (24) (Ming et al., 2001; Yamauchi et al., 2015), griffithazanone A (25) (Zhang et al., 1999), cleistopholine (26) (Waterman and Muhammad, 1985), vanillic acid (27) (Wu et al., 2000), p-hydroxybenzoic acid (28) (Rukachaisirikul et al., 2010), p-methylbenzoicacid (29) (Zhou et al., 2013), 4-hydroxy-3-methoxypropiophenone (30) (Ito et al., 2001), 3,5-dimethoxy-4-hydroxypropiophenone (31) (Zdero et al., 1986), p-hydroxybenzaldehyde (32) (Zhou et al., 2013), ethyl-4-hydrozybenzoate (33) 
(Fan et al., 2016), trans-ferulic acid (34) (Salum et al., 2010), (-)-(3R)-mellein methyl ether (35) (Li et al., 2017), derrusnin (36) (East et al., 1969), 5-hydroxy-7-methoxy3',4'-methylene dioxy isoflavone (37) (Liping et al., 1996), derrustone (38) (Singh and Muthukrishnan, 2005), robustone methyl ether (39) (East et al., 1969), derrugenin (40) (Ortega et al., 2015), robustigenin (41) (Pancharoen et al., 2008), methyl-BRM-5 (42) (Tahara et al., 1986), trans- $N$-coumaroyltyramine (43) (Holzbach and Lopes, 2010), and $N$-trans-feruloyl tyramine (44) (Holzbach and Lopes, 2010) by comparison of their spectroscopic data with those published.

Compound 1, goniochelienic acid A, was obtained as yellow needles. The core structure of compound $\mathbf{1}$ was a benzo[f]indole-4,9-dinone (Efdi et al., 2010) which was confirmed by a single-crystal X-ray diffraction analysis using Mo $\mathrm{K} \alpha$ radiation (Fig. 5). The HRESIMS spectrum showed a $[\mathrm{M}+\mathrm{Na}]^{+}$ion peak at $\mathrm{m} / z 294.0379$ (calcd. for $\mathrm{C}_{14} \mathrm{H}_{9} \mathrm{NO}_{5} \mathrm{Na}$, 294.0378) which also supported this structural assignment. The ${ }^{1} \mathrm{H}$ NMR spectrum of $\mathbf{1}$ (Table 1) showed resonances for a hydroxy proton of a carboxylic acid $\left[\delta_{\mathrm{H}} 13.68(\mathrm{COOH})\right]$, a H-bonded hydroxy proton $\left[\delta_{\mathrm{H}} 12.20(1 \mathrm{H}, \mathrm{s}, 8-\right.$ $\mathrm{OH})]$, aromatic protons of an $\mathrm{ABC}$ spin system $\left[\delta_{\mathrm{H}} 7.82(1 \mathrm{H}, \mathrm{d}, J=7.4 \mathrm{~Hz}, \mathrm{H}-5) / \delta_{\mathrm{C}}\right.$ $120.7,7.64(1 \mathrm{H}, \mathrm{dd}, J=7.8,7.4 \mathrm{~Hz}, \mathrm{H}-6) / \delta_{\mathrm{C}} 136.0,7.32(1 \mathrm{H}, \mathrm{d}, J=7.8 \mathrm{~Hz}, \mathrm{H}-7) / \delta_{\mathrm{C}}$ $126.1]$, an olefinic proton $\left[\delta_{\mathrm{H}} 7.74(1 \mathrm{H}, \mathrm{s}, \mathrm{H}-2) / \delta_{\mathrm{C}} 138.0\right]$, and a $N$-methyl group $\left[\delta_{\mathrm{H}}\right.$ $\left.4.15\left(3 \mathrm{H}, \mathrm{s}, N-\mathrm{CH}_{3}\right) / \delta_{\mathrm{C}} 37.5\right]$. The structure of 1 was further supported by the following key HMBC correlations (Fig. 3): $\delta_{\mathrm{H}} 12.20(8-\mathrm{OH})$ with C-7 $\left(\delta_{\mathrm{C}} 126.1\right)$, C-8 $\left(\delta_{\mathrm{C}} 162.5\right)$, and C-8a $\left(\delta_{\mathrm{C}} 114.5\right) ; \delta_{\mathrm{H}} 7.82(\mathrm{H}-5)$ with $\mathrm{C}-4\left(\delta_{\mathrm{C}} 183.1\right)$ and $\mathrm{C}-6\left(\delta_{\mathrm{C}}\right.$ $136.0) ; \delta_{\mathrm{H}} 4.15(N-\mathrm{Me})$ with C-9a $\left(\delta_{\mathrm{C}} 130.9\right), \mathrm{C}-2\left(\delta_{\mathrm{C}} 138.0\right) ; \delta_{\mathrm{H}} 7.74(\mathrm{H}-2)$ with C-3 $\left(\delta_{\mathrm{C}} 114.5\right), \mathrm{C}-3 \mathrm{a}\left(\delta_{\mathrm{C}} 123.5\right), \mathrm{C}-9 \mathrm{a}\left(\delta_{\mathrm{C}} 130.9\right)$, and C-10 $\left(\delta_{\mathrm{C}} 161.5\right)$. From these data, the structure of compound $\mathbf{1}$ was assigned as 8-hydroxyl-1-methyl-4,9-dioxy- $1 H$ benz $[f]$ indole-3-catboxylic acid. Full assignments of the ${ }^{1} \mathrm{H}$ and ${ }^{13} \mathrm{C}$ NMR spectroscopic data are shown in Table 1.

Compound 2, goniochelienic acid $\mathrm{B}$, was isolated as a yellow powder. Its molecular formula, $\mathrm{C}_{14} \mathrm{H}_{9} \mathrm{NO}_{4}$, was established by the HRESIMS which showed a [M $+\mathrm{Na}]^{+}$ion peak at $\mathrm{m} / \mathrm{z} 278.0436$ (calcd. for $\mathrm{C}_{14} \mathrm{H}_{9} \mathrm{NO}_{4} \mathrm{Na}, 278.0429$ ). The ${ }^{1} \mathrm{H}$ and ${ }^{13} \mathrm{C}$ NMR spectroscopic data (Table 1) of $\mathbf{2}$ were similar to those of $\mathbf{1}$. The main difference between these two compounds was that the H-bonded proton at $\delta_{\mathrm{H}} 12.22$ (OH-8) was not observed in the ${ }^{1} \mathrm{H}$ NMR spectrum of 2 . Compound 2 showed ${ }^{1} \mathrm{H}$ NMR resonances for four aromatic protons, that formed part of a 1,2-disubstituted aromatic ring, at $\delta_{\mathrm{H}} 8.26(1 \mathrm{H}, \mathrm{dd}, J=1.3,7.4 \mathrm{~Hz}, \mathrm{H}-5), 7.79(1 \mathrm{H}, \mathrm{td}, J=1.5,7.5 \mathrm{~Hz}$, $\mathrm{H}-6), 7.81(1 \mathrm{H}, \mathrm{td}, J=1.5,7.5 \mathrm{~Hz}, \mathrm{H}-7), 8.21(1 \mathrm{H}, \mathrm{dd}, J=7.4,1.3 \mathrm{~Hz}, \mathrm{H}-8)$ instead of the $\mathrm{ABC}$ spin system observed in the ${ }^{1} \mathrm{H}$ NMR spectrum of compound 1 . Finally, the structure of $\mathbf{2}$ was supported with the following key HMBC correlations (Fig. 3): $\delta_{\mathrm{H}} 8.26(\mathrm{H}-5)$ with C-4 $\left(\delta_{\mathrm{C}} 184.0\right)$ and C-6 $\left(\delta_{\mathrm{C}} 134.5\right) ; \delta_{\mathrm{H}} 4.16(N-\mathrm{Me})$ with C-9a $\left(\delta_{\mathrm{C}}\right.$ $131.8), \mathrm{C}-2\left(\delta_{\mathrm{C}} 137.5\right) ; \delta_{\mathrm{H}} 7.73(\mathrm{H}-2)$ with $\mathrm{C}-3\left(\delta_{\mathrm{C}} 116.4\right), \mathrm{C}-3 \mathrm{a}\left(\delta_{\mathrm{C}} 123.1\right), \mathrm{C}-9 \mathrm{a}\left(\delta_{\mathrm{C}}\right.$ $131.8)$, and $\mathrm{C}-10\left(\delta_{\mathrm{C}} 162.1\right)$. Therefore, compound 2 was assigned as 1-methyl-4,9dioxy- $1 H$-ben $[f]$ indole-3-carboxylic acid.

Compound 3, methyl goniochelienate, was isolated as a yellow amorphous powder. The molecular formula $\mathrm{C}_{14} \mathrm{H}_{9} \mathrm{NO}_{4}$ was deduced from HRESIMS analysis which showed a $[\mathrm{M}+\mathrm{Na}]^{+}$at $\mathrm{m} / 2.278 .0435$ (calcd for $\mathrm{C}_{14} \mathrm{H}_{9} \mathrm{NO}_{4} \mathrm{Na}, 278.0429$ ). The 
${ }^{1}$ H NMR spectroscopic data of $\mathbf{3}$ (Table 1 ) were similar to those of $\mathbf{4}$; whose structure was determined by single crystal X-ray structural analysis (Fig. 6). The difference between compounds $\mathbf{3}$ and $\mathbf{4}$ is that $\mathbf{3}$ has a C-3 methoxy carbonyl substituent $\left(\delta_{\mathrm{H}}\right.$ 3.89) and $\mathbf{4}$ has a C-3 methyl group. The position of the methoxy group in $\mathbf{3}$ was confirmed by the $\mathrm{HMBC}$ correlation from $\delta_{\mathrm{H}} 3.89\left(3-\mathrm{CO}_{2} \mathrm{Me}\right)$ with $\mathrm{C}-10\left(\delta_{\mathrm{C}} 163.2\right)$ (Fig. 3). The other key HMBC correlations were shown in Fig. 3. Therefore, the structure of $\mathbf{3}$ was identified as methyl 4,9-dioxo- $1 H$-benz $[f]$ indole-3-catboxylate.

Compound $\mathbf{5}$ was obtained as a yellow solid. The molecular formula of $\mathbf{5}$ was established as $\mathrm{C}_{13} \mathrm{H}_{11} \mathrm{NO}_{5}$ based on the HRESIMS $\left(\mathrm{m} / z 284.0530[\mathrm{M}+\mathrm{Na}]^{+}\right.$, calcd for $\mathrm{C}_{13} \mathrm{H}_{11} \mathrm{NO}_{5} \mathrm{Na}$ 284.0535). The ${ }^{1} \mathrm{H}$ and ${ }^{13} \mathrm{C}$ NMR spectra of 5 in $\mathrm{CDCl}_{3}$ solution shown resonances characteristic of a naphthoquinone derivative (Table 2), which were similar to those of goniothalaminone B (45), previously isolated from Goniothalamus scortechinii (Prawat et al., 2012). The significant difference between these two compounds was observed for the chemical shift of H-7/C-7 and H-8/C-8. Compound 5 displayed these resonances at $\delta_{\mathrm{H}} 7.05(1 \mathrm{H}, \mathrm{d}, J=8.4 \mathrm{~Hz}, \mathrm{H}-7) / \delta_{\mathrm{C}} 113.2$ and 7.75 $(1 \mathrm{H}, \mathrm{d}, J=8.4 \mathrm{~Hz}, \mathrm{H}-8) / \delta_{\mathrm{C}} 121.0$, whereas for goniothalaminone B these appeared at $\delta_{\mathrm{H}} 7.22(1 \mathrm{H}, \mathrm{d}, J=8.4 \mathrm{~Hz}, \mathrm{H}-7) / \delta_{\mathrm{C}} 117.8$ and $\delta_{\mathrm{H}} 7.76(1 \mathrm{H}, \mathrm{d}, J=8.4 \mathrm{~Hz}, \mathrm{H}-8) / \delta_{\mathrm{C}}$ 120.7 (Table 2). In addition, the chemical shifts for C-2, C-3 and C-6 were also different; $\delta_{\mathrm{C}} 106.9(\mathrm{C}-2)$ and $\delta_{\mathrm{C}} 158.4(\mathrm{C}-3) 155.8(\mathrm{C}-6)$ for compound $\mathbf{5}$ and $\delta_{\mathrm{C}} 109.4$ $(\mathrm{C}-2), \delta_{\mathrm{C}} 152.5(\mathrm{C}-3)$ and $\delta_{\mathrm{C}} 152.1(\mathrm{C}-6)$ for goniothalaminone B. These data indicated that compound $\mathbf{5}$ was a structural isomer of goniothalamin B. To help further assign all ${ }^{1} \mathrm{H}$ NMR resonances as well as to confirm the location of amino group, the NMR spectra of compound 5 were also recorded in DMSO- $d_{6}$. The ${ }^{1} \mathrm{H}$ NMR spectrum in DMSO- $d_{6}$ (Table 2) showed addition downfield resonances at $\delta_{\mathrm{H}}$ $9.12(1 \mathrm{H}, \mathrm{br} \mathrm{s})$ and $\delta_{\mathrm{H}} 10.68(1 \mathrm{H}, \mathrm{br} \mathrm{s})$ assignable to the primary amine protons. Finally, the structure was further confirmed from the following $\mathrm{HMBC}$ correlations: $\delta_{\mathrm{H}} 10.68\left(2-\mathrm{NH}_{2}\right)$ with C-1 $\left(\delta_{\mathrm{C}} 178.1\right) ; \delta_{\mathrm{H}} 3.91(6-\mathrm{OMe})$ with C-6 $\left(\delta_{\mathrm{C}} 155.8\right) ; \delta_{\mathrm{H}} 13.94$ $(5-\mathrm{OH})$ with C-6 $\left(\delta_{\mathrm{C}} 155.8\right), \mathrm{C}-5\left(\delta_{\mathrm{C}} 151.6\right), \mathrm{C}-4 \mathrm{a}\left(\delta_{\mathrm{C}} 114.3\right) ; \delta_{\mathrm{H}} 7.62(\mathrm{H}-8)$ with C-1 $\left(\delta_{\mathrm{C}} 178.1\right), \mathrm{C}-8 \mathrm{a}\left(\delta_{\mathrm{C}} 121.8\right)$, and $\mathrm{C}-7\left(\delta_{\mathrm{C}} 114.7\right)$ (Fig. 3 and S27). Thus, the structure of $\mathbf{5}$ was identified as goniochelieninone, a structural isomer of goniothalamin B. Full assignments of the ${ }^{1} \mathrm{H}$ and ${ }^{13} \mathrm{C}$ NMR spectroscopic data are shown in Table 2 and the COSY and selected HMBC correlations in Fig. 3.

Plausible biosynthetic pathways of compounds 1-5 are shown in Fig.11. Compounds 1-4 and 5 might arise from difference polyketide units (Wagoner et al., 2008; King et al., 2009; Bauer et al., 2010). The benzo[f]indole-4,9-diones 1-4 could be obtain from a hexaketide generated from an isobutyryl-CoA starter and a five acetyl-CoA extender (Zhou et al., 2016) involving multi-steps including the incorporation of nitrogen (Fig. 11a) (Wagoner et al., 2008; Bauer et al., 2010). Compound 4 undergoes oxidation of the methyl group to give the carboxylic acid derivative (4a), esterification of $\mathbf{4 a}$ would yield compound $\mathbf{3}$. Alternatively, $\mathbf{4 a}$ was regioselectively $N$-methylated to obtain compound $\mathbf{2}$ which was then oxidized at C-8 to give compound $\mathbf{1}$. The naphthoquinone $\mathbf{5}$ might arise from heptaketide (Fig. 11b) with the similar process of $\mathbf{4}$. 
Compound 6 was isolated as a colorless prism. Analysis of its HRESIMS showed a $[\mathrm{M}+\mathrm{Na}]^{+}$ion peak at $m / z 273.0749$ (calcd for $\mathrm{C}_{13} \mathrm{H}_{14} \mathrm{O}_{5} \mathrm{Na}, 273.0739$ )

216 which established the molecular formula $\mathrm{C}_{13} \mathrm{H}_{14} \mathrm{O}_{5}$. The 5,7-dihydroxy-8217 phenylbicyclo[3.3.1]nonan-2-one based structure and the absolute configuration $218(4 S, 5 S, 6 R, 7 S, 8 S)$ of compound 6 were established by single-crystal X-ray diffraction 219 analysis using $\mathrm{Cu} \mathrm{K} \alpha$ radiation (Fig. 7) with the flack parameter of -0.04(7). The ECD 220 spectrum of 6 (Fig. 9) displayed a negative Cotton effect at $227 \mathrm{~nm}$, similar to that of 221 parvistone D and parvistone E (Liuo et al., 2014) which also supported the 222 identification of its absolute configuration. The ${ }^{1} \mathrm{H}$ NMR spectrum further supported 223 this structure and showed resonances for the mono substituted aromatic ring at $\delta_{\mathrm{H}} 7.38$ $224\left(2 \mathrm{H}, \mathrm{d}, J=7.9 \mathrm{~Hz}, \mathrm{H}-2^{\prime} / 6^{\prime}\right), 7.30\left(2 \mathrm{H}, \mathrm{d}, J=7.6 \mathrm{~Hz}, \mathrm{H}-3^{\prime} / 5^{\prime}\right)$ and $7.26(1 \mathrm{H}, \mathrm{d}, J=7.2$ $\left.225 \mathrm{~Hz}, \mathrm{H}-4^{\prime}\right)$. The structure of compound $\mathbf{6}$ was almost identical to that of (+)226 goniopypyrone except for the configuration at C-7 which was $7 S$ for compound 6 and $2277 R$ for (+)-goniopypyrone (Tsubuki et al., 1999; Zhang et al., 1998). The ${ }^{1} \mathrm{H}$ NMR 228 spectroscopic data of these two compounds were significantly different, except for the 229 aromatic proton chemical shifts, as shown in Table S1. Thus, compound 6 was 230 assigned as (-)-(4S,5S,6R,7S,8S)-goniochelienlactone, the $\mathrm{C}-7$ epimer of (+)231 goniopypyrone.

232 Compound 7 was isolated as a colorless prism. Its molecular formula $233 \mathrm{C}_{15} \mathrm{H}_{16} \mathrm{O}_{6}$ was established the HRESIMS analysis which showed a $[\mathrm{M}+\mathrm{Na}]^{+}$ion peak 234 at $m / z 315.0854$ (calcd for $\mathrm{C}_{15} \mathrm{H}_{16} \mathrm{O}_{6} \mathrm{Na}, 315.0845$ ). The core structure of compound 7 235 was a [3.3.1] bicyclic, similar to that found in compound 6. A single-crystal X-ray 236 diffraction analysis of compound 7 using $\mathrm{Cu} \mathrm{K} \alpha$ radiation established the structure of 237 compound 7 and its absolute configuration as $4 S, 5 S, 6 R, 7 S, 8 S$ (Fig. 8) with the Flack 238 parameter 0.00 (11). Its ECD spectrum (Fig. 9) was similar to that of compound 6 239 which showed the Cotton effect at $232 \mathrm{~nm}$ to support the $4 S, 5 S, 6 R, 7 S, 8 S$ 240 configuration. The full assignments of its ${ }^{1} \mathrm{H}$ and ${ }^{13} \mathrm{C}$ NMR spectroscopic data are 241 summarized in Table 3. It should be noted that compound 7 is the C-7 is epimer of 7242 acetylgoniopypyrone (Zhang et al., 1998). Differences were also observed between 243 these epimers from their ${ }^{1} \mathrm{H}$ NMR spectra, especially the chemical shifts for the 244 [3.3.1] bicyclic protons as shown in Table S2. Thus, the structure of 7 was identified as (-)-(4S,5S,6R,7S,8S)-7-acetylgoniochelienlactone.

Compound 8, (+)-(7S,8S)-goniochelienbutenolide $\mathrm{A}$, was obtained as a colorless viscous oil. Its molecular formula $\mathrm{C}_{15} \mathrm{H}_{14} \mathrm{O}_{5}$ was deduced from its HRESIMS $\left(m / z\right.$ 297.0730 $\left[\mathrm{M}+\mathrm{Na}^{+}\right.$, calcd for $\left.\mathrm{C}_{15} \mathrm{H}_{14} \mathrm{O}_{5} \mathrm{Na}, 297.0739\right)$. The ${ }^{1} \mathrm{H}$ and ${ }^{13} \mathrm{C}$ NMR spectroscopic data of $\mathbf{8}$ were similar to those of goniobutenolide A (Fang et al., 1991). The main difference between compounds 8 and goniobutenolide $\mathrm{A}$ was that compound 8 displayed an additional ${ }^{1} \mathrm{H}$ NMR resonance for acetoxy protons at $\delta_{\mathrm{H}}$ 2.12. Additionally, the resonances for $\mathrm{H}-7\left(\delta_{\mathrm{H}} 5.10\right)$ and $\mathrm{H}-8\left(\delta_{\mathrm{H}} 5.88\right)$ of compound 8 were shifted downfield compared to the same protons of goniobutenolide $\mathrm{A},\left[\delta_{\mathrm{H}} 4.98\right.$ $(\mathrm{H}-7)$ and $4.94(\mathrm{H}-8)$ ], (SI Table S3 and S4). The HMBC correlations between $\mathrm{H}-8$ $\left(\delta_{\mathrm{H}} 5.85\right)$ with the acetate carbonyl carbon $\left(\delta_{\mathrm{C}} 168.0\right), \mathrm{H}-2^{\prime} / \mathrm{H}-6^{\prime}\left(\delta_{\mathrm{H}} 7.40\right)$ with $\mathrm{C}-8\left(\delta_{\mathrm{C}}\right.$ $76.5)$ and $\mathrm{H}-7\left(\delta_{\mathrm{H}} 4.98\right)$ with $\mathrm{C}-8\left(\delta_{\mathrm{C}} 76.5\right)$ supported the position of the acetoxy group 
at C-8 (Fig. 3). The relative stereochemistry of $\mathbf{8}$ was proposed to be ethyro based on the coupling constant of $\mathrm{H}-7 / \mathrm{H}-8\left(J_{7,8}=6.0 \mathrm{~Hz}\right)$ indicating their syn orientation $\left(J_{7,8}=\right.$ 6-8 Hz) (Fang et al., 1991, Shing et al., 1994; Xu et al., 1994). The Z-geometry of C$5 / \mathrm{C}-6$ was determined from a comparison of the ${ }^{1} \mathrm{H}$ NMR spectroscopic data to those of 7-epi-goniobutenolide A and B (SI Table S3 and S4). The absolute configuration of $8(7 S, 8 S)$ was proposed by the comparison of its ECD spectrum to that of compound 11 which showed a negative Cotton effect at 230 and $274 \mathrm{~nm}$ (Fig. 10). Thus, the structure of compound $\mathbf{8}$ was deduced as (7S,8S,Z)-5-(3-acetyl-2-hydroxy-3phenylpropylidene)-2(5H)-furanone.

Compound 9, (-)-(7S,8R)-goniochelienbutenolide $\mathrm{B}$, was obtained as a colorless viscous oil. It molecular formula $\mathrm{C}_{15} \mathrm{H}_{14} \mathrm{O}_{5}$ was established by HRESIMS $\left(m / z \quad 297.0746[\mathrm{M}+\mathrm{Na}]^{+}\right.$, calcd for $\mathrm{C}_{15} \mathrm{H}_{14} \mathrm{O}_{5} \mathrm{Na}$, 297.0739). The ${ }^{1} \mathrm{H} \mathrm{NMR}$ spectroscopic data of 9 were similar to that of 8 (Table 4 and SI Fig.S3), but H-3 ( $\delta_{\mathrm{H}}$ 6.19) of compound 9 showed long range coupling with that of $\mathrm{H}-6\left(\delta_{\mathrm{H}} 5.82\right)$ with the $J$ value of $1.5 \mathrm{~Hz}$ indicating the $E$-geomety at the exo-cyclic alkene isomer of compound 9 (Fang et al., 1991; Popsavin et al., 2012). The oxymethine protons of C-7 and C-8 were assigned the threo configuration on the basis of their coupling constant $J_{7,8}=4.2 \mathrm{~Hz}$ (Fang et al., 1991; Shing et al., 1995; Popsavin et al., 2012). The absolute configuration of $\mathbf{9}$ as $7 S, 8 R$ was proposed from the comparison of its ECD spectrum to that of $\mathbf{1 0}$ (Fig. 10). Therefore, the structure was characterized as $(7 S, 8 R$, E)-5-(3-acetyl-2-hydroxy-3-phenylpropylidene)-2(5H)-furanone.

Annonaceae is a large family containing over 120 genera (Saripalli and Dixit, 2013). Each genus produces different major phytochemicals. For example, polyoxygenated cyclohexenes are commonly found in many species of Uvaria (Awale et al., 2017; Lekphrom et al., 2018; Hsu et al., 2016; Kaweetripob et al., 2015; Auranwiwat et al., 2017; Macabeo et al., 2017), but they are also found in some species of Artabotrys (Liu et al., 2018), Cleistochlamys (Nyandoro et al., 2017), Dasymaschalon (Hongthong et al., 2015), Ellipeiopsis (Kijjoa et al., 2002), and Monanthotaxis (Starks et al., 2012) genera. Flavonoids are major compounds from many genera including Desmos (Clement et al., 2017; Tuntipaleepun et al., 2012; Kuo et al., 2015; Prachyawarakorn et al., 2013; Bajgai et al., 2011; Rittiwong et al., 2011), and Friesodielsia (Meesakul et al., 2017; Prawat et al., 2012; Fleischer et al., 1997; Joseph et al., 2007), while alkaloids, including aristololactams, aporphines and oxoprotoberberine, are commonly found in the Miliusa (Promchai et al., 2018; Promchai et al., 2016; Hasan et al., 2000; Chen et al., 2003; Harrigan et al., 1994) and Fissistigma (Ge et al., 2013; Zhou et al., 2016; Zhou et al., 2018; Chia et al., 2000) genera. Styryllactones are the major compounds found in Goniothalamus (Moharam et al., 2012; Macobeo et al., 2013; Zhang et al., 1998; Fang et al., 1991., Suchaichit et al., 2015, Hisham et al., 2000; Uma et al., 2012) and Polyalthia (Nantapap et al., 2015; Nurunajah et al., 2001; Samoath and Vasanthi, 2013) whereas acetogenin (Moghadamtousi et al., 2015; Dang et al., 2011; Melot et al., 2009; Liaw et al., 2008; Sun et al., 2017; Guzmán et al., 2009; Liaw et al., 2004; Queiroz et al., 2003) and

299 diterpenoids (Supudompol et al., 2004; Li et al., 2005; Li et al., 2009; Deepralard et al., 2007; Meng et al., 2007) were found in Annona and Mitrephora. 

$\mathbf{2 8}, \mathbf{3 0}, \mathbf{3 1}, \mathbf{3 4}, \mathbf{3 6}-\mathbf{3 9}$ ) were evaluated for their cytotoxicities against the colon cancer cell line HCT-116. Only compound 25 (griffithazanone A) showed potent cytotoxicity with an $\mathrm{IC}_{50}$ value of $2.39 \mu \mathrm{M}$ (doxorubicin as a positive control had an $\mathrm{IC}_{50}$ value of $9.74 \mu \mathrm{M})$. All remaining compounds were inactive $\left(\mathrm{IC}_{50}>50 \mu \mathrm{M}\right)$. The $\mathrm{IC}_{50}$ value of compound 25 against HCT-116 is less than those against human cervical cancer cells (20.2 $\mu \mathrm{M}$ and $11.7 \mu \mathrm{M}$ for $\mathrm{KB}$ cells and HeLa cells, respectively) (Tip-pyang et al., 2010). Indicating that the cytotoxic effect of compound 25 is not cell-line specific and that compound $\mathbf{2 5}$ may be more effective against colorectal cancer cell lines than cervical cancer cell lines.

\section{Conclusions}

The phytochemical investigation of the extracts of the G. cheliensis led to the identification of 44 compounds, of which eight were previously undescribed compounds (1-3, 5, and 6-9). The discovery of styryllactones as the major compounds was in good agreement with the previous report of this genus (Moharam et al., 2012; Macobeo et al., 2013; Zhang et al., 1998; Fang et al., 1991., Suchaichit et al., 2015, Hisham et al., 2000; Uma et al., 2012). To the best of our knowledge, the indole alkaloids 1-3 and alkaloid $\mathbf{5}$ were found in this species for the first time. In a previous paper, the [3.3.1] bicyclic core structure of compounds 6 and 7 was reported as having the $7 R$ configuration (Fang et al., 1991; Tsubuki et al., 1999; Zhang et al., 1998), however, we report herein related compounds having the $7 S$ configuration with their absolute configurations being confirmed by single-crystal X-ray diffraction analysis. The isolated compounds were found to have no cytotoxicities against the colon cancer cell line HCT-116 at $50 \mu \mathrm{M}$ except for griffithazanone A (25) which had potent cytotoxicities. This compound may have potential as a lead compound for the development of new anti-cancer agents.

\section{Experiment section}

\subsection{General experiment procedures}

The optical rotation $[\alpha]_{\mathrm{D}}$ values were determined with a Bellingham and Stanley ADP400 polarimeter. Melting points were measured with a Buchi B-540 melting point apparatus. UV-vis spectra were recorded with Varian Cary 5000 UVvis-NIR spectrophotometer. The IR spectra were recorded using a Perkin-Elmer FTS FT-IR spectrophotometer. Electronic circular dichroism spectra were recorded on a JASCO J-815 CD spectropolarimeter. The NMR spectra were recorded using Bruker Avance $600 \mathrm{MHz}$ spectrometers. Chemical shifts are reported in parts per million $(\delta)$, and coupling constants $(J)$ are expressed in hertz. HRESIMS spectra were obtained on a Bruker-Hewlett-Packard 1100 Esquire-LC system mass spectrometer. Single-crystal X-ray diffraction measurements were made on a Bruker APEX DUO diffractometer with cross-coupled multilayer optics $\mathrm{Cu}-\mathrm{K} \alpha$ radiation. HPLC was performed on a Waters 1525 HPLC pump system, equipped with a Waters 2487 dual $\lambda$ absorbance detector using the following column: Phenomenex Luna $5 \mathrm{u} \mathrm{C}_{8}$ column $(10 \times 250 \mathrm{~mm})$ 
and CHIRALCEL OD-H column $(4.6 \times 250 \mathrm{~mm})$. Quick column chromatography (QCC) and column chromatography (CC) were carried out on Si gel $60 \mathrm{H}(5-40 \mu \mathrm{m}$, Merck), Si gel $100\left(63-200 \mu \mathrm{m}\right.$, Merck) or silica gel $100\left(63-200 \mu \mathrm{m}\right.$, SiliCycle $^{\circledR}$ Inc.), respectively. Waters $10 \mathrm{~g}$ Sep-Pak's were used for reversed-phase flash chromatography. Sephadex LH-20 was also used for CC. Precoated plates of silica gel $60 \mathrm{~F}_{254}$ were used for analytical purposes.

\subsection{Plant material}

The twigs and leaves of Goniothalamus cheliensis $\mathrm{Hu}$ (Annonaceae) were collected from Doi Tung, Chiang Rai Province, Thailand (GPS coordinates: $20^{\circ} 17.351^{\prime} \mathrm{N}, 99^{\circ} 48.661^{\prime} \mathrm{E}$ ), in October 2015, winter. The plant material was authenticated by Mr. Martin van de Bult (Doi Tung Development Project, Chiang Rai, Thailand), and a voucher specimen (MFU-NPR0146) was deposited at the Natural Products Research Laboratory, School of Science, Mae Fah Luang University.

\subsection{Extraction and isolation}

The dried twigs of $G$. cheliensis $(5.1 \mathrm{~kg})$ were extracted with acetone. The acetone extract (41.2 g) was subjected to QCC eluting with a gradient solvent system of $n$-hexanes-acetone (1:0 to $0: 1, \mathrm{v} / \mathrm{v})$ to afford 11 fractions $(\mathrm{A}-\mathrm{K})$. Fraction D (2.3 g) was subjected to Sephadex LH-20 $(100 \% \mathrm{MeOH})$ to yield seven subfractions $\left(\mathrm{D}_{1}-\mathrm{D}_{7}\right)$. Fraction $\mathrm{D}_{4}(95.8 \mathrm{mg})$ was subjected to Sep-Pak $\mathrm{C}_{18} \mathrm{CC}$, eluted with $\mathrm{MeOH}-\mathrm{H}_{2} \mathrm{O}(3: 2, \mathrm{v} / \mathrm{v})$ to yield subfraction $\mathrm{D}_{1} \mathrm{~A}$. Fraction $\mathrm{D}_{1} \mathrm{~A}(61.6 \mathrm{mg})$ was separated over Sephadex LH-20 to give 4 subfractions $\left(\mathrm{D}_{1} \mathrm{~A}-1-\mathrm{D}_{1} \mathrm{~A}-4\right)$. Fraction $\mathrm{D}_{1} \mathrm{~A}-2(40.4 \mathrm{mg})$ was fractionated using silica gel CC eluting with $n$-hexanes-acetone $(7: 3, v / v)$ to obtained 6 subfractions $\left(\mathrm{D}_{1} \mathrm{~A}-2-1-\mathrm{D}_{1} \mathrm{~A}-2-6\right)$. Fraction $\mathrm{D}_{1} \mathrm{~A}-2-2$ (4.5 mg) was chromatographed using RP $\mathrm{C}_{18}$ HPLC (eluted with $\mathrm{CH}_{3} \mathrm{CN} / \mathrm{H}_{2} \mathrm{O}$ with $0.05 \%$ TFA, $1: 1,2 \mathrm{~mL} / \mathrm{min})$ to give compounds 29 and $\mathbf{3 2}\left(0.3 \mathrm{mg}, t_{\mathrm{R}}=11.6 \mathrm{~min}\right), \mathbf{3 0}(1.0$ $\left.\mathrm{mg}, t_{\mathrm{R}}=15.6 \mathrm{~min}\right)$, and $33\left(0.9 \mathrm{mg}, t_{\mathrm{R}}=18.5 \mathrm{~min}\right)$. Compound $31\left(2.1 \mathrm{mg}, t_{\mathrm{R}}=15.6\right.$ min) was obtained from $\mathrm{D}_{1} \mathrm{~A}-2-3$ by $\mathrm{RP} \mathrm{C}_{18}$ HPLC (eluted with $\mathrm{CH}_{3} \mathrm{CN} / \mathrm{H}_{2} \mathrm{O}$ with $0.05 \%$ TFA, $1: 1,2 \mathrm{~mL} / \mathrm{min})$. Fraction $\mathrm{D}_{5}(205.0 \mathrm{mg})$ was subjected to Sep-Pak $\mathrm{C}_{18}$ $\mathrm{CC}$, eluted with $\mathrm{MeOH}-\mathrm{H}_{2} \mathrm{O}(3: 2, \mathrm{v} / \mathrm{v})$ to give subfraction $\mathrm{D}_{5} \mathrm{~A}(172.6 \mathrm{mg})$ following separated by Sephadex LH-20 (100\% MeOH) to yield 4 subfractions ( $\left.\mathrm{D}_{5} \mathrm{~A}-1-\mathrm{D}_{5} \mathrm{~A}-4\right)$. Compound $35(3.9 \mathrm{mg})$ and $28(1.4 \mathrm{mg})$ were purified from $\mathrm{D}_{5} \mathrm{~A}-2(47.5 \mathrm{mg})$ by silica gel CC eluting with $n$-hexanes-acetone $(7: 3, \mathrm{v} / \mathrm{v})$. Fraction $\mathrm{D}_{7}(29.4 \mathrm{mg})$ was subjected to Sep-Pak $\mathrm{C}_{18} \mathrm{CC}$ eluting with $\mathrm{MeOH}-\mathrm{H}_{2} \mathrm{O}(3: 2, \mathrm{v} / \mathrm{v})$ to give $\mathrm{D}_{7} \mathrm{~A}(26.1$ $\mathrm{mg}$ ) and further separation on a silica gel $\mathrm{CC}$ eluting with $\mathrm{CH}_{2} \mathrm{Cl}_{2}-\mathrm{MeOH}(97: 3, \mathrm{v} / \mathrm{v})$ to yield compound $5(0.8 \mathrm{mg})$. Fraction $\mathrm{E}(14.9 \mathrm{mg})$ was subjected to RP $\mathrm{C}_{8}$ HPLC (eluted with $\mathrm{CH}_{3} \mathrm{CN} / \mathrm{H}_{2} \mathrm{O}$ with $0.05 \%$ TFA, $\left.3: 2,2 \mathrm{~mL} / \mathrm{min}\right)$ to give compound 2 (1.0 $\left.\mathrm{mg}, t_{\mathrm{R}}=12.8 \mathrm{~min}\right)$ and compound $1\left(2.1 \mathrm{mg}, t_{\mathrm{R}}=13.6 \mathrm{~min}\right)$. Fraction $\mathrm{F}(8.9 \mathrm{~g})$ was partition with $\mathrm{CH}_{2} \mathrm{Cl}_{2}$ and water, the $\mathrm{CH}_{2} \mathrm{Cl}_{2}$ soluble fraction $(7.9 \mathrm{~g})$ was subjected to silica gel CC, eluting with a gradient of $\mathrm{CH}_{2} \mathrm{Cl}_{2}-\mathrm{MeOH}(99: 1$ to $19: 1$, v/v) to afford 7 subfractions (F1-F7). Fraction F2 $(912.8 \mathrm{mg})$ was chromatographed on a silica gel $\mathrm{CC}$ eluting with $\mathrm{CH}_{2} \mathrm{Cl}_{2}-\mathrm{MeOH}(99: 1, \mathrm{v} / \mathrm{v})$ to afford compound $4(1.1 \mathrm{mg})$ and 4 subfractions (F2-1-F2-4). Fraction F2-2 (588.0 mg) was subjected to Sephadex LH- 
$20 \mathrm{CC}(100 \% \mathrm{MeOH})$ to afford 5 subfractions (F2-2-1-F2-2-5). Fraction F2-2-1 $\left(114.5 \mathrm{mg}\right.$ ) was purified using RP $\mathrm{C}_{8}$ HPLC (eluted with $\mathrm{CH}_{3} \mathrm{CN} / \mathrm{H}_{2} \mathrm{O}$ with $0.05 \%$ TFA, $3: 7,2 \mathrm{~mL} / \mathrm{min})$ to afford compounds $8\left(1.1 \mathrm{mg}, t_{\mathrm{R}}=34.9 \mathrm{~min}\right), \mathbf{9}\left(0.3 \mathrm{mg}, t_{\mathrm{R}}=\right.$ $48.7 \mathrm{~min}$ ), and seven subfractions (F2-2-1-1-F2-2-1-7). Fraction F2-2-1-3 and F2-21-6 were subjected to $\mathrm{RP} \mathrm{C}_{8}$ HPLC (eluted with $\mathrm{CH}_{3} \mathrm{CN} / \mathrm{H}_{2} \mathrm{O}$ with $0.05 \%$ TFA, 3:7, 2 $\mathrm{mL} / \mathrm{min})$ to yield compounds $16\left(7.7 \mathrm{mg}, t_{\mathrm{R}}=40.5 \mathrm{~min}\right), \mathbf{1 3}\left(1.3 \mathrm{mg}, t_{\mathrm{R}}=62.9 \mathrm{~min}\right), 7$ $\left(0.9 \mathrm{mg}, t_{\mathrm{R}}=70.0 \mathrm{~min}\right), 14\left(1.7 \mathrm{mg}, t_{\mathrm{R}}=81.9 \mathrm{~min}\right)$, and $15\left(1.1 \mathrm{mg}, t_{\mathrm{R}}=91.4 \mathrm{~min}\right)$. Fraction F2-2-2 (257.7 mg) was chromatographed on silica CC eluting with $n$ hexanes-acetone (7:3, v/v) to give 5 subfractions (F2-2-2-1-F2-2-2-5). Fraction F2-22-2 (11.8 mg) was subjected to RP $\mathrm{C}_{8}$ HPLC (eluted with $\mathrm{CH}_{3} \mathrm{CN} / \mathrm{H}_{2} \mathrm{O}$ with $0.05 \%$ TFA, 3:7, $2 \mathrm{~mL} / \mathrm{min})$ to yield compound $26\left(0.7 \mathrm{mg}, t_{\mathrm{R}}=20.6 \mathrm{~min}\right)$. Compound 20 $\left(3.9 \mathrm{mg}, t_{\mathrm{R}}=29.1 \mathrm{~min}\right)$, enantiomeric mixtures of $\mathbf{1 7}$ and $\mathbf{1 8}\left(1.9 \mathrm{mg}, t_{\mathrm{R}}=15.2 \mathrm{~min}\right)$, 23 and $21\left(0.7 \mathrm{mg}, t_{\mathrm{R}}=29.1 \mathrm{~min}\right)$ and 19 and $22(15.7 \mathrm{mg})$ were obtained from fraction F2-2-2-4 (28.5 mg). The chiral column OD-H (eluted with $n$-hexanes/MeOH, $3: 2,2 \mathrm{~mL} / \mathrm{min})$ was used to yield compounds $17\left(0.2 \mathrm{mg}, t_{\mathrm{R}}=10.9 \mathrm{~min}\right)$ and $\mathbf{1 8}(0.4$ $\left.\mathrm{mg}, t_{\mathrm{R}}=11.4 \mathrm{~min}\right), \mathbf{2 3}\left(0.3 \mathrm{mg}, t_{\mathrm{R}}=9.2 \mathrm{~min}\right)$ and $21\left(0.2 \mathrm{mg}, t_{\mathrm{R}}=10.9 \mathrm{~min}\right)$, and $\mathbf{1 9}$ $\left(5.2 \mathrm{mg}, t_{\mathrm{R}}=6.3 \mathrm{~min}\right)$ and $22\left(6.9 \mathrm{mg}, t_{\mathrm{R}}=7.4 \mathrm{~min}\right)$. Fraction F2-2-4 (13.7 mg) was subjected to RP $\mathrm{C}_{18}$ HPLC (eluted with $\mathrm{CH}_{3} \mathrm{CN} / \mathrm{H}_{2} \mathrm{O}$ with $0.05 \%$ TFA, 2:3, 2 $\mathrm{mL} / \mathrm{min})$ to give compounds $24\left(0.5 \mathrm{mg}, t_{\mathrm{R}}=14.1 \mathrm{~min}\right)$ and $25\left(1.9 \mathrm{mg}, t_{\mathrm{R}}=11.8\right.$ $\mathrm{min})$. Compound $3\left(1.8 \mathrm{mg}, t_{\mathrm{R}}=15.9 \mathrm{~min}\right.$ ) was purified by $\mathrm{RP} \mathrm{C}_{8}$ HPLC (eluted with $\mathrm{CH}_{3} \mathrm{CN} / \mathrm{H}_{2} \mathrm{O}$ with $0.05 \% \mathrm{TFA}, 3: 7,2 \mathrm{~mL} / \mathrm{min}$ ) from fraction $\mathrm{F} 2-2-5$ (8.4 mg). Compound $34\left(1.0 \mathrm{mg}, t_{\mathrm{R}}=9.9 \mathrm{~min}\right)$ was purified from fraction $\mathrm{F} 3(435.7 \mathrm{mg})$ by QCC over silica gel, eluting with a gradient of $\mathrm{CH}_{2} \mathrm{Cl}_{2}-\mathrm{MeOH}$ gradient (99:1 to 97:3, $\mathrm{v} / \mathrm{v})$ to give 4 subfractions (F3-1-F3-4), with each of these purified with $\mathrm{RP} \mathrm{C}_{18}$ HPLC (eluted with $\mathrm{CH}_{3} \mathrm{CN} / \mathrm{H}_{2} \mathrm{O}$ with $0.05 \%$ TFA, 2:3, $2 \mathrm{~mL} / \mathrm{min}$ ) and Sephadex LH$20(100 \% \mathrm{MeOH})$. Fraction $\mathrm{G}(10.8 \mathrm{~g})$ was chromatographed on a silica gel $\mathrm{CC}$ eluting with $\mathrm{CH}_{2} \mathrm{Cl}_{2}-\mathrm{MeOH}(95: 5$, v/v) to give 10 subfractions (G1-G10). Fraction G3 $\left(15.7 \mathrm{mg}\right.$ ) was purify using RP $\mathrm{C}_{8} \mathrm{HPLC}$ (eluted with $\mathrm{CH}_{3} \mathrm{CN} / \mathrm{H}_{2} \mathrm{O}$ with $0.05 \%$ TFA, $3: 7,2 \mathrm{~mL} / \mathrm{min})$ to give compound $12\left(1.7 \mathrm{mg}, t_{\mathrm{R}}=7.4 \mathrm{~min}\right)$. Fraction $\mathrm{G} 4$ (142.3 mg) was subjected to silica gel CC, eluted with $\mathrm{CH}_{2} \mathrm{Cl}_{2}-\mathrm{MeOH}(97: 3$, v/v) following RP $\mathrm{C}_{8}$ HPLC (eluted with $\mathrm{CH}_{3} \mathrm{CN} / \mathrm{H}_{2} \mathrm{O}$ with $0.05 \%$ TFA, $1: 3,2 \mathrm{~mL} / \mathrm{min}$ ) to give compounds $27\left(5.2 \mathrm{mg}, t_{\mathrm{R}}=14.2 \mathrm{~min}\right), \mathbf{1 0}\left(0.4 \mathrm{mg}, t_{\mathrm{R}}=23.3 \mathrm{~min}\right)$, and $11\left(0.3 \mathrm{mg}, t_{\mathrm{R}}\right.$ $=24.6 \mathrm{~min})$. Compound $6(36.9 \mathrm{mg})$ was recrystallized from $n$-hexanes-acetone (1:1, v/v) from subfraction G6 $(234.7 \mathrm{mg})$.

The dried leaves of $G$. cheliensis $(412.1 \mathrm{~g})$ were extracted with acetone $(3 \times 3$ $\mathrm{L})$ at room temperature. The acetone extract (33.8 g) was subjected to QCC over silica gel, eluting with a gradient of $n$-hexanes-acetone gradient $(1: 0$ to $0: 1, \mathrm{v} / \mathrm{v})$ to afford fourteen fractions $(\mathrm{A}-\mathrm{N})$. The combined of fraction $\mathrm{E}-\mathrm{H}$ were further separated on a Sep-Pak $\mathrm{C}_{18} \mathrm{CC}$ eluting with $\mathrm{MeOH}-\mathrm{H}_{2} \mathrm{O}(1: 1, \mathrm{v} / \mathrm{v})$ to give fraction $\mathrm{B} 1(819.4 \mathrm{mg})$ and further separation by silica gel $\mathrm{CC}$, eluting with $n$-hexanes-acetone $(9: 1, \mathrm{v} / \mathrm{v})$ gave 5 subfractions (B1-1-B1-5). Fraction B1-3 (73.2 mg) was purified by RP $\mathrm{C}_{8}$ HPLC (eluted with $\mathrm{CH}_{3} \mathrm{CN} / \mathrm{H}_{2} \mathrm{O}$ with $0.05 \%$ TFA, $3: 2,2 \mathrm{~mL} / \mathrm{min}$ ) to yield compounds 37 $\left(2.0 \mathrm{mg}, t_{\mathrm{R}}=24.7 \mathrm{~min}\right)$ and $42\left(1.3 \mathrm{mg}, t_{\mathrm{R}}=37.3 \mathrm{~min}\right)$. The combination of fraction $\mathrm{I}-\mathrm{K}$ was subjected to Sep-Pak $\mathrm{C}_{18} \mathrm{CC}$ eluting with $\mathrm{MeOH}-\mathrm{H}_{2} \mathrm{O}(1: 1$, v/v) to give 
fraction C1 (806.4 mg) and further separation by Sephadex LH-20 CC (100\% MeOH) to yield six subfractions (C1-1-C1-6). Fraction C1-3 (8.7 mg) was purified by silica gel CC, eluting with $n$-hexanes-acetone $(7: 3, \mathrm{v} / \mathrm{v})$ to give compound $39(1.7 \mathrm{mg})$ and 5 subfractions (C1-3-1-C1-3-5). Compounds 36 (1.4 mg, $\left.t_{\mathrm{R}}=32.8 \mathrm{~min}\right)$ and 41 (0.9 $\left.\mathrm{mg}, t_{\mathrm{R}}=34.0 \mathrm{~min}\right)$ were obtained from subfraction $\mathrm{C} 1-3-5(4.5 \mathrm{mg})$, by a $\mathrm{RP} \mathrm{C}_{8}$ HPLC (eluted with $\mathrm{CH}_{3} \mathrm{CN} / \mathrm{H}_{2} \mathrm{O}$ with $0.05 \%$ TFA, $1: 1,2 \mathrm{~mL} / \mathrm{min}$ ). After further purification by RP $\mathrm{C}_{8}$ HPLC (eluted with $\mathrm{CH}_{3} \mathrm{CN} / \mathrm{H}_{2} \mathrm{O}$ with $0.05 \%$ TFA, 1:1, 2 $\mathrm{mL} / \mathrm{min})$, compounds $38\left(2.1 \mathrm{mg}, t_{\mathrm{R}}=20.7 \mathrm{~min}\right)$ and $\mathbf{4 0}\left(0.4 \mathrm{mg}, t_{\mathrm{R}}=23.5 \mathrm{~min}\right)$ were obtained from subfraction $\mathrm{C} 1-4(6.1 \mathrm{mg})$. The combined of fractions $\mathrm{L}-\mathrm{N}$ were further separated by Sephadex LH-20 CC $(100 \% \mathrm{MeOH})$ to give nine subfractions (D1-D9). Fraction D6 (18.2 mg) was isolated by RP $\mathrm{C}_{18}$ HPLC (eluted with $\mathrm{CH}_{3} \mathrm{CN} / \mathrm{H}_{2} \mathrm{O}$ with $0.05 \%$ TFA, $\left.3: 7,2 \mathrm{~mL} / \mathrm{min}\right)$ to afford compounds $43\left(0.3 \mathrm{mg}, t_{\mathrm{R}}=\right.$ $28.9 \mathrm{~min})$ and $44\left(0.8 \mathrm{mg}, t_{\mathrm{R}}=30.5 \mathrm{~min}\right)$.

\subsubsection{Goniochelienic acid A (1)}

Yellow needle; mp $215-217{ }^{\circ} \mathrm{C}$; UV $(\mathrm{MeOH}) \lambda_{\max }(\log \varepsilon) 253$ (3.47), 287 (3.08), 328 (2.51) nm; IR (neat) $v_{\max } 2920,2850,1721,1451,1236,747 \mathrm{~cm}^{-1}$; For ${ }^{1} \mathrm{H}-$ NMR (600 MHz, $\mathrm{CDCl}_{3}$ ) and ${ }^{13} \mathrm{C}-\mathrm{NMR}\left(125 \mathrm{MHz}, \mathrm{CDCl}_{3}\right)$, see Table 1; HRESIMS (positive-ion mode) $m / z 294.0379[\mathrm{M}+\mathrm{Na}]^{+}$(calcd for $\mathrm{C}_{14} \mathrm{H}_{9} \mathrm{NO}_{5} \mathrm{Na}, 294.0378$ ).

\subsubsection{Goniochelienic acid B (2)}

Yellow amorphous solid; mp 220-222 ${ }^{\circ} \mathrm{C}$; UV (MeOH) $\lambda_{\max }(\log \varepsilon) 253$ (3.74), 278 (3.33), 331 (2.95) nm; IR (neat) $v_{\max }$ 2918, 2850, 1727, 1459, 1228, 717 $\mathrm{cm}^{-1}$; For ${ }^{1} \mathrm{H}-\mathrm{NMR}\left(600 \mathrm{MHz}, \mathrm{CDCl}_{3}\right.$ ) and ${ }^{13} \mathrm{C}-\mathrm{NMR}\left(125 \mathrm{MHz}, \mathrm{CDCl}_{3}\right)$, see Table 1; HRESIMS (positive-ion mode) $m / z 278.0436[\mathrm{M}+\mathrm{Na}]^{+}$(calcd for $\mathrm{C}_{14} \mathrm{H}_{9} \mathrm{NO}_{4} \mathrm{Na}$, 278.0429).

\subsubsection{Methyl goniochelienate (3)}

Yellow solid; mp 214-216 ${ }^{\circ} \mathrm{C}$; UV (MeOH) $\lambda_{\max }(\log \varepsilon) 251$ (4.37), 276 (3.95), 309 (3.53), 3.74 (3.13) nm; IR (neat) $v_{\max }$ 2924, 2853, 1678, 1208, $1135 \mathrm{~cm}^{-1}$; For ${ }^{1} \mathrm{H}-\mathrm{NMR}\left(600 \mathrm{MHz}, \mathrm{MeOH}-d_{4}\right)$ and ${ }^{13} \mathrm{C}-\mathrm{NMR}\left(125 \mathrm{MHz}, \mathrm{MeOH}-d_{4}\right)$, see Table 1; HRESIMS (positive-ion mode) $\mathrm{m} / z$ 2 $278.0435[\mathrm{M}+\mathrm{Na}]^{+}$(cald for $\mathrm{C}_{14} \mathrm{H}_{9} \mathrm{NO}_{4} \mathrm{Na}$, 278.0429).

\subsubsection{Goniochelieninone (5)}

Yellow solid; mp $162-165{ }^{\circ} \mathrm{C}$; UV $(\mathrm{MeOH}) \lambda_{\max }(\log \varepsilon) 215$ (3.53), 282 (3.20), 417 (2.59) nm; IR (neat) $v_{\max } 3335,3215,2920,2851,1615,1452,1371,1260$ $\mathrm{cm}^{-1}$; For ${ }^{1} \mathrm{H}-\mathrm{NMR}\left(600 \mathrm{MHz}, \mathrm{CDCl}_{3}\right.$ ) and ${ }^{13} \mathrm{C}-\mathrm{NMR}\left(125 \mathrm{MHz}, \mathrm{CDCl}_{3}\right.$ ), see Table 2; HRESIMS (positive-ion mode) $m / z 284.0530[\mathrm{M}+\mathrm{Na}]^{+}$(calcd for $\mathrm{C}_{13} \mathrm{H}_{11} \mathrm{NO}_{5} \mathrm{Na}$, 284.0535).

\section{3 .5 (-)-(4S,5S,6R,7S,8S)-Goniochelienlactone $(\mathbf{6})$}

Colorless solid; mp $215-217{ }^{\circ} \mathrm{C}$; $[\alpha]^{25}-47.0$ (c 0.1, EtOH); UV (EtOH) $\lambda_{\max }$ $(\log \varepsilon) 215$ (2.76), $255(1.51) \mathrm{nm} ; \mathrm{CD}(\mathrm{EtOH}) \lambda_{\max }(\Delta \varepsilon) 227(-0.89) \mathrm{nm}$; IR (neat) 
$v_{\max } 3395,2925,2873,2853,1713,1177,1081 \mathrm{~cm}^{-1} ;{ }^{1} \mathrm{H}$ NMR $\left(600 \mathrm{MHz}, \mathrm{DMSO}-d_{6}\right)$ and ${ }^{13} \mathrm{C}$ NMR (125 MHz, DMSO- $d_{6}$ ) data, see Table 3; HRESIMS (positive-ion mode) $m / z, 273.0749[\mathrm{M}+\mathrm{Na}]^{+}$(calcd for $\mathrm{C}_{13} \mathrm{H}_{14} \mathrm{O}_{5} \mathrm{Na}, 273.0739$ ).

\subsection{6 (-)-(4S,5S,6R,7S,8S)-7-acetylgoniochelienlactone (7)}

Colorless solid; mp $152-155^{\circ} \mathrm{C}$; $[\alpha]^{25}$ D -58.0 (c 0.1, EtOH); UV (EtOH) $\lambda_{\max }$ $(\log \varepsilon) 212(2.69), 249(0.97) \mathrm{nm}$; CD (EtOH) $\lambda_{\max }(\Delta \varepsilon) 232(-0.26) \mathrm{nm}$; IR (neat) $v_{\max } 3422,2924,1731,1220,1054 \mathrm{~cm}^{-1} ;{ }^{1} \mathrm{H}$ NMR $\left(600 \mathrm{MHz}, \mathrm{CDCl}_{3}\right)$ and ${ }^{13} \mathrm{C} \mathrm{NMR}$ (125 MHz, $\mathrm{CDCl}_{3}$ ) data, see Table 3; HRESIMS (positive-ion mode) $\mathrm{m} / \mathrm{z} 315.0854$ $[\mathrm{M}+\mathrm{Na}]^{+}$(calcd for $\mathrm{C}_{15} \mathrm{H}_{16} \mathrm{O}_{6} \mathrm{Na}, 315.0845$ ).

\subsection{7 (+)-(7S, $8 S)-$ Goniochelienbutenolide A $(\mathbf{8})$}

Colorless viscous; $[\alpha]_{\mathrm{D}}^{25}+55.0(c \quad 0.1 \mathrm{EtOH}) ; \mathrm{UV}(\mathrm{EtOH}) \lambda_{\max }(\log \varepsilon) 206$ (2.9), $273(2.8) \mathrm{nm}$; CD (EtOH) $\lambda_{\max }(\Delta \varepsilon) 227(-0.30), 274(-0.59) \mathrm{nm}$; IR (neat) $v_{\max }$ 3419, 2926, 1682, 1750, 1208, $1135 \mathrm{~cm}^{-1} ;{ }^{1} \mathrm{H}$ NMR (600 MHz, acetone- $\left.d_{6}\right)$ and ${ }^{13} \mathrm{C}$ NMR (125 MHz, acetone- $d_{6}$ ) data, see Table 4; HRESIMS (positive-ion mode) $\mathrm{m} / \mathrm{z}$ 297.0730 $[\mathrm{M}+\mathrm{Na}]^{+}$(calcd for $\mathrm{C}_{15} \mathrm{H}_{14} \mathrm{O}_{5} \mathrm{Na}, 297.0739$ ).

\subsection{8 (-)-(7S,8R)-Goniochelienbutenolide B (9)}

Colorless viscous; $[\alpha]_{\mathrm{D}}^{25}-34.0\left(c 0.1 \mathrm{CHCl}_{3}\right) ; \mathrm{UV}\left(\mathrm{CHCl}_{3}\right) \lambda_{\max }(\log \varepsilon) 225$ (2.9), $274(2.8) \mathrm{nm} ; \mathrm{CD}\left(\mathrm{CHCl}_{3}\right) \lambda_{\max }(\Delta \varepsilon) 228(+0.04), 281(+0.76) \mathrm{nm}$; IR (neat) $v_{\max } 3472,2922,2852,1743,1236 \mathrm{~cm}^{-1} ;{ }^{1} \mathrm{H} \mathrm{NMR}\left(600 \mathrm{MHz}, \mathrm{CDCl}_{3}\right)$ and ${ }^{13} \mathrm{C} \mathrm{NMR}$ (125 MHz, $\mathrm{CDCl}_{3}$ ) data, see Table 4; HRESIMS (positive-ion mode) $\mathrm{m} / \mathrm{z} 297.0746$ $[\mathrm{M}+\mathrm{Na}]^{+}$(calcd for $\mathrm{C}_{15} \mathrm{H}_{14} \mathrm{O}_{5} \mathrm{Na}, 297.0739$ ).

\section{$4.4 X$-ray crystal analysis of compounds $1,4,6$, and 7}

$\mathrm{X}$-ray diffraction data were collected using Mo Ka radiation $(\lambda=0.71073 \AA)$ and $\mathrm{Cu} \mathrm{K \alpha}$ radiation $(\lambda=1.54178 \AA$ ) on a Bruker APEX-II CCD diffractometer. Using Olex2 (Dolomanov et al., 2009), the structure was solved with the XT (Sheldrick, 2015) structure solution program, using the Intrinsic Phasing solution method. The model was refined with version 2018/1 of XL (Sheldrick, 2015) using Least Squares minimisation. Crystallographic data of compounds 1, 4, 6, and 7 have been deposited at the Cambridge Crystallographic Data Center under the reference number CCDC 1846457 (1), 1846454 (4), 1846455 (6), and 1846456 (7). These data can be obtained, free of charge, from the Cambridge Crystallographic Data Centre via http://www.ccdc.cam.ac.uk/data_request/cif.

\subsubsection{Crystal data of 1}

Crystals of 1 were obtained as orange irregular-shaped crystals from $\mathrm{Me}_{2} \mathrm{CO}$ hexanes. $\mathrm{C}_{31} \mathrm{H}_{24} \mathrm{~N}_{2} \mathrm{O}_{11}, M_{r}=600.52$, monoclinic, space group $\mathrm{C} 2 / \mathrm{c}$ (No. 15), $\mathrm{a}=$ 13.549(6) $\AA, b=26.964(12) \AA, c=8.522(4) \AA, \beta=122.191(10)^{\circ}, \alpha=\gamma=90^{\circ}, V=$ 2635(2) $\AA^{3}, T=90(2) \mathrm{K}, Z=4, Z^{\prime}=0.5, \mu\left(\right.$ Mo $\left.\mathrm{K}_{\alpha}\right)=0.117,9693$ reflections 
measured, 1731 unique $\left(R_{\text {int }}=0.0813\right)$ which were used in all calculations. The final $w R_{2}$ was 0.1937 (all data) and $R_{l}$ was $0.0692(\mathrm{I}>2(\mathrm{I})$ ).

\subsubsection{Crystal data of 4}

Crystals of 4 were obtained as orange needle-shaped crystals from $\mathrm{Me}_{2} \mathrm{CO}$ hexanes. $\mathrm{C}_{13} \mathrm{H}_{9} \mathrm{NO}_{2}, M_{r}=211.21$, monoclinic, space group $\mathrm{P}_{1} / \mathrm{c}$ (No. 14), a = 15.1793(14) $\AA, \mathrm{b}=3.8477(5) \AA, \mathrm{c}=17.6197(18) \AA, \beta=109.578(5)^{\circ}, \alpha=\gamma=90^{\circ}, V=$ 969.59(19) $\AA^{3}, T=100(2) \mathrm{K}, Z=4, Z^{\prime}=1, \mu\left(\right.$ Mo $\left.\mathrm{K}_{\alpha}\right)=0.099,9656$ reflections measured, 2298 unique $\left(R_{\text {int }}=0.0343\right)$ which were used in all calculations. The final $w R_{2}$ was 0.1790 (all data) and $R_{1}$ was 0.0602 (I $>2(\mathrm{I})$ ).

\subsubsection{Crystal data of 6}

Crystals of $\mathbf{6}$ were obtained as colourless irregular-shaped crystals from $\mathrm{Me}_{2} \mathrm{CO}$-hexanes. $\mathrm{C}_{13} \mathrm{H}_{14} \mathrm{O}_{5}, M_{r}=250.24$, orthorhombic, space group $\mathrm{P}_{1} 2_{1} 2_{1}$ (No. 19), $\mathrm{a}=9.4413(5) \AA, \mathrm{b}=10.3844(6) \AA, \mathrm{c}=11.6131(6) \AA, \alpha=\beta=\gamma=90^{\circ}, V=$ 1138.57(11) $\AA^{3}, T=90(2) \mathrm{K}, Z=4, Z^{\prime}=1, \mu\left(\mathrm{Cu} \mathrm{K} \mathrm{K}_{\alpha}\right)=0.948,9069$ reflections measured, 2012 unique $\left(R_{\text {int }}=0.0325\right)$ which were used in all calculations. The final $w R_{2}$ was 0.0615 (all data) and $R_{l}$ was 0.0241 (I $>2(\mathrm{I})$ ). Flack parameter $=-0.04(7)$.

\subsubsection{Crystal data of 7}

Crystals of 7 were obtained as colourless irregular-shaped crystals from $\mathrm{Me}_{2} \mathrm{CO}$-hexanes. $\mathrm{C}_{15} \mathrm{H}_{16} \mathrm{O}_{6}, M_{r}=292.28$, monoclinic, $\mathrm{P} 2_{1}$ (No. 4), a $=10.9487(4) \AA$, $\mathrm{b}=6.8358(3) \AA, \mathrm{c}=18.6909(7) \AA, \beta=90.243(2)^{\circ}, \alpha=\gamma=90^{\circ}, V=1398.87(10) \AA^{3}, T$ $=90(2) \mathrm{K}, Z=4, Z^{\prime}=2, \mu\left(\mathrm{Cu} \mathrm{K}_{\alpha}\right)=0.910,20213$ reflections measured, 4945 unique $\left(R_{\text {int }}=0.0351\right)$ which were used in all calculations. The final $w R_{2}$ was 0.0900 (all data) and $R_{l}$ was $0.0336(\mathrm{I}>2(\mathrm{I})$ ). Flack parameter $=0.00(11)$.

\subsection{Biological assay}

\subsubsection{Bioassay for Cytotoxicity}

The cytotoxicities of compounds on colon cancer cell were performed following by the previous method (Sriyatep et al., 2017). Doxorubicin used as a positive control $\left(\mathrm{IC}_{50}=9.74 \mu \mathrm{M}\right)$.

\section{Acknowledgements}

This research was financially supported by the Thailand Research Fund and Mae Fah Luang University through the Basic Research Grant (BRG5980012), the Thailand Research Fund through the Royal Golden Jubilee Ph.D. Program (PHD/0019/2557) and Direct Basic Research Grant (DBG5980001) and the Mae Fah Luang University Graduate Student Research Grant. University of British Columbia is also acknowledged for laboratory facilities. We would like to thank Mr. Martin van de Bult, Doi Tung Development Project, Chiang Rai, Thailand for plant collection and identification.

\section{Appendix A. Supplementary data}

Supplementary data related to this article can be found at 


\section{References}

Auranwiwat, C., Wongsomboon, P., Thaima, T., Rattanajak, R., Kamchonwongpaisan, S., Willis, A.C., Lie, W., Pyne, S.G., Limtharakul, T., 2017. 2-Phenylnaphthalenes and a polyoxygenated cyclohexene from the stem and root extracts of Uvaria cherrevensis (Annonaceae). Fitoterapia 120, 103-107.

Awale, S., Tawia, A.M., Dibwe, D.F., Ueda, J., Sun, S., Athikomkulchai, S., Balachandran, C., Saiki, I., Matsumoto, K., Esumi, H., 2017. Highly oxygenated antiausterity agents from the leaves of Uvaria dac. Bioorg. Med. Chem. Lett. 27, 1967-1971.

Bajgai, S.P., Prachyawarakorn, V., Mahidol, C., Ruchirawat, S., Kittakoop, P., 2011. Hydrid flavan-chalcones, aromatase and lipoxygenase inhitors, from Desmos chochinchinensis. Phytochemistry 72, 2062-2067.

Bauer, J.D., King, R.W., Brady, S.F., 2010. Utahmycins A and B, azaquinones produced by an environmental DNA clone. J. Nat. Prod. 73, 976-979.

Chang, C.W., Chang, H.S., Cheng, M.J., Peng, C.F., Chen, I.S., 2015. Identification of five new minor constituents from the whole plant of Amischotolype hispida. Helv. Chim. Acta. 98, 347-358.

Chen, B., Feng, C., Li, B.G., Zhang, G.L., 2003. Two new alkaloids from Miliusa cuneate. Nat. Prod. Res. 17, 397-402.

Chia, Y.C., Chang, F.R., Teng, C.M., Wu, Y.C., 2000. Aristolactams and dioxoaporphines from Fissistigma balansae and Fissistigma oldhamii. J. Nat. Prod. 63, 1160-1163.

Chen, C.Y., Wu, T.Y., Chang, F.R., Wu, Y.C., 1998. Lignans and kauranes from the stems of Annona cherimola. J. Chin. Chem. Soc. 45, 6294-634.

Clement, J.A., Ondeyka, J.G., Goetz, M.A., 2017. Benzoate esters and flavonoids from Desmos pedunculosus. Phytochem. Lett. 22, 117-121.

Colegate, S.M., Din, L.B., Latiff, A., Salleh, K.M., Samsudin, M.W., Skelton, B.W., Tadano, K.I., White, A.H., Zakaria, Z., 1990. (+)-Isoaltholactone: a furanopyrone isolated from Goniothalamus species. Phytochemistry 29, 1701-1704.

Dang, Q.L., Kim, W.K., Nguyen, C.M., Choi, Y.H., Choi, G.J., Jang, K.S., Park, M.S., Lim, C.H., Luu, N.H., Kim, J.C., 2011. Nematicidal and antifungal activities of Annonaceous acetogenins from Annona squamosal against various plant pathogens. J. Chem. Food Chem. 59, 11160-11167.

Deepralard, K., Pengsuparp, T., Moriyasu, M., Kawanishi, K., Suttisri, R., 2007. Chemical constituents of Mitrephora maingayi. Biochem. Syst. Ecol. 35, 695-699.

Dolomanov, O.V., Bourhis, L.J., Gildea, R.J., Howard, J.A.K., Puschmann, H., 2009. Olex2: A complete structure solution, refinement and analysis program. J. Appl. Cryst. 42, 339-341.

Duc, L.V., Thanh, T.B., Thanh, H.N., Tien, V.N., 2016. Chemical constituents and cytotoxic effect from the barks of Goniothalamus cheliensis Merr. \& Chun. growing in Vietnam. J. Appl. Pharm. Sci. 6, 1-5. 
East, A.J., Ollis, W.D., Wheeler, R.E., 1969. Natural occurrence of 3-aryl-4hydroxycoumarins. Part I. Phytochemical examination of Derris robusta (Roxb.) Benth. J. Chem. Soc. 365-374.

Efdi, M., Fujita, S., Inuzuka, T., Koketsu., 2010. Chemical studies on Goniothalamus tapis Miq. Nat. Prod. Res. 24, 657-662.

Fang, X.P., Andersen, J. E., Chang, C.J., Mclaighlin, J.L., 1991. Two new styryl lactones, 9-deoxygoniopypyrone and 7-epi-goniofufurone, from Goniothalamus giganteus. J. Nat. Prod. 54, 1034-1043.

Fan, C.M., Chou, G.X., Zhu, E.Y., 2016. Chemical constituents from Crotalaria sessiliflora L. Acta. Pharmacol. Sin. 51, 775-779.

Fleischer, T.C., Waigh, R.D., Waterman, P.G., 1997. Bisabolene sesquiterpenes and flavonoids from Friesodielsia enghiana. Phytochemistry 44, 315-318.

Ge, Y.W., Zhu, S., Shang, M.Y., Zang, X.Y., Wang, X., Bai, Y.J., Li. L., Komatsu, K., Cai, S.Q., 2013. Aristololactams and aprophines from the stems of Fissistigma oldhamii (Annonaceae). Phytochemistry 86, 201-207.

Schlie-Guzmán, M.A., García-Carrancá, A., González-Esquinca., 2009. In vitro and in vivo antiproliferative activity of Laherradurin and cherimolin-2 of Annona diverifolia Saff. Phytother. Res. 24, 1128-1133.

Harrigan, G.G., Gunatilaka, A.A.L., Kingston, D.G., 1994. Ioslation of bioactive and other oxoaporphine alkaloids from two annonaceous plants, Xylopia aethiopica and Miliusa CF. banacea. J. Nat. Prod. 57, 68-73.

Hasan, C.M., Jumana, S., Rashid, M.A., 2000. (+)-Isocorydine $\alpha$ - $N$-oxide: a new aporphine alkaloid from Miliusa velutina. Nat. Prod. Lett. 14, 393-397.

Heyne, K., 1950. De nuttige planten van Indonesie, 3rd ed., Wageningen: H. Veenman and Konen.

Hishman, A., Harassi, A., Shuaily, W., Echigo, S., Fujimoto, Y., 2000. Cardiopetaolactone: A novel styryllactones from Goniothalamus cardiopetalus. Tetrahedron 56, 9985-9989.

Holzbach, J.C., Lope, L.M.X., 2010. Aristolactams and alkaloids of Aristolochia gigantean. Molecules 15, 9462-9472.

Hongthong, S., Kuhakarn, C., Jaipetch, T., Prabpai, S., Kongsaeree, P., Piyachaturawat, P., Jariyawat, S., Suksen, K., Limthongkul, J., Panthong, A., Nuntasaen, N., Reutrakul, V., 2015. Polyoxzygenated cyclohexene derivatives isolated from Dasymaschalon sootepense and their biological activities. Fitoterapia 106, 158-166.

Hsu., Y.M., Wu, T.Y., Du, Y.C., Shazly, M.E., Beerhues, L., Thang, T.D., Luu, H.V., Hwang, T.L., Chang, F.R., Wu, Y.C., 2016. 3-Methyl-4,5,dihydro-oxepine, polyoxygenated seco-cyclohexenes and cyclohexenes from Uvaria flexuosa and their anti-inflammatory activity. Phytochemistry 122, 184-192.

Ito, J., Chang, F.R., Wang, H.K., Park, Y.K., Ikegaki, M., Kilgore, N., Lee, K.H., 2001. Anti-AIDS agents. 48. ${ }^{1}$ anti-HIV activity of moronic acid derivatives and the new melliferone-related triterpenoid isolated from Brazilian propolis. J. Nat. Prod. 64, 1278-1281. 
Ichimaru, M., Nakatani, N., Moriyasu, M., Nishiyama, Y., Kato, A., Mathenge, S.G., Juma, F.D., Chalomutiso, P.B., 2010. Hydroxyespintanol and schefflerichalcone: two new compounds from Uvaria scheffleri. J. Nat. Med. 64, 75-79.

Jiang, M.M., Feng, Y.F., Gao, H., Zhang, X., Tang, J.S., Yao, X.S., 2011. Three new bis-styryllactones from Goniothalamus cheliensis. Fitoterapia 82, 524-527.

Jiang, M.M., Feng, Y.F., Zhang, X., Yao, X.S., 2011. Chemical constituents from roots of Goniothalamus cheliensis (II). Chin. Tradit. Herbal Drugs. 12, 23862388.

Jiang, M.M., Wen, R., Rui, W., Fu, F.F., Zhao, L., Yao, X., Feng, Y., 2011. Analysis of styryllactones from Goniothalalmus cheliensis by UPLC-Q-TOF-MS. China J. Chin. Mat. Med. 36, 1323-1326.

Jiang, M.M., Zhang, X., Dai, Y., Gao, H., Lui, H.W., Wang, N.L., Ye, W.C., Yao, X.S., 2008. Alkaloids from the root barks of Goniothalamus cheliensis. Chin. Chem. Lett. 19, 302-304.

Joseph, C.C., Magadula, J.J., Nkunya, M.H.H., 2007. A novel antiplasmodial 3',5'diformylchalcone and other constituents of Friesodielsia obovate. Nat. Prod. Res. 21, 1009-1015.

Kampong, R., Pompimon, W., Meepowpan, P., Sukdee, S., Sombutsiri, P., Nantasaen, N., Krachodnok, S., 2013. (-)-7-O-acetylgoniodiol as cancer chemopreventive agent from Goniothalamus griffithii. Int. J. Chem. Sci. 11, 1234-1246.

Kaweetripob, W., Mahidol, C., Prawat, H., Ruchirawat, S., 2015. Cyclohexene longchain fatty acid esters from Uvaria dulcis (Dunal). Phytochem. Lett. 12, $248-251$.

Khallouki, F., Haubner, R., Ulrich, C.M., Owen, R.W., 2011. Ethnobotanical survey, chemical composition, and antioxidant capacity of methanolic extract of the root bark of Annona cuneata Oliv. J. Med. Food. 14, 1397-1402.

Kijjoa, A., Bessa, J., Pinto, M.M.M., Anatachoke, C., Silva, A.M.S., Eaton, G., Herz, W., 2002. Polyoxygenated cyclohexene derivatives from Ellipeiopsis cherrevensis. Phytochemistry 59, 543-549.

King, R.W., Bauer, J.D., Brady, S.F., 2009. An environmental DNA-derived type II polyketide biosynthetic pathway encodes the biosynthesis of the pentacyclic polyketide erdacin. Angew. Chem. Int. Ed. 48, 6257-6261.

Kuo, P.C., Thang, T.D., Huang, G.J., Huang, B.S., Hoa, L.T.M., Yang, M.L., Wu, T.S., 2015. Flavonoids from the fruits of Desmos cochinchinesis var. fulvecens and their inhibitory effect on NO production. Chem. Nat. Compd. 51, $152-155$.

Lekphrom, R., Kanokmedhakul, K., Schevenels, F., Kanokmedhakul, S., 2018. Antimalaria polyoxygenated cyclohexene derivatives freom the roots of Uvaria cherrevensis. Fitoterapia 127, 420-424.

Li, Chen., Lee, D., Graf, T.N., Phifer, S.S., Nakanishi, Y., Burgess, J.P., Riswan, S., Setyowati, F.M., Saribi, A.M., Soejarto, D.D., Farnsworth, N.R., Falkinham, J.O., Kroll, D.J., Kinghorn, A.D., Wani, C.C., Oberlies, N.H., 2005. A 
hexacyclic enttrachylobane diterpenoid possessing an oxetane ring from Mitrephora glaba. Org. Lett. 7, 5709-5712.

Li, Chen., Lee, D., Graf, T.N., Phifer, S.S., Nakanishi, Y., Riswan, S., Setyowati, F.M., Saribi, A.M., Soejarto, D.D., Farnsworth, N.R., Falkinham, J.O., Kroll, D.J., Kinghorn, A.D., Wani, M.C., Oberlies, N.H., 2009. Bioactive constituents of the stem bark of Mitrephora glabra. J. Nat. Prod. 72, 1949-1953.

Liaw, C.C., Chang, F.R., Wu, Y.C., Wang, H.K., Nakanishi, Y., Bastow, K.F., Lee, K.H., 2004. Montacin and cis-montacin, two new cytotoxic monotetrahydrofuran Annonaceae acetogenins from Annona montana. J. Nat. Prod. 67, 1804-1808.

Liaw, C.C., Yang, Y.L., Chen, M., Chang, F.R., Chen, S.L., Wu, S.H., Wu, Y.C., 2008. Mono-tetradydrofuran Annonaceae acetogenins from Annona squamosal as cytotoxic agents and calcium ion chelators. J. Nat. Prod. 71, 764-771.

Li, W., Wiesenfeldt, M.P., Glorius, F., 2017. Ruthenium-NHC-diamine catalyzed enantioselective hydrogenation of isocoumarins. 139, 2585-2588.

Liping, Z., Meigua, J., Changqi, H., 1996. Studies on isoflavones from Chinese peashrub (Caragana sinica). Zhongcaoyao 27, 134-136.

Liou, J.R., Wu, T.Y., Thang, T.D., Hwang, T.L., Wu, C.C., Cheng, Y.B., Chiang, M.Y., Lan, Y.H., El-Shazly, M., Wu, S.L., Beerhues, L., Yuan, S.S., Hou, M.F., Chen, S.L., Chang, F.R., Wu, Y.C., 2014. Bioactive $6 S$-styryllactone constituents of Polyalthia parviflora. J. Nat. Prod. 77, 2626-2632.

Lui, Y.P., Tang, J.Y., Hua, Y., Lai, L., Luo, X.L., Zhang, Z.J., Yin, W.Q., Chen, G.Y., Fu, Y.H., 2018. Bioactive polyoxygenated seco-cyclohexenes from Artabotrys hongkongensis. Bioorg. Chem. 76, 386-391.

Lui, Y.P., Wang, X.C., Li, X.B., Li, K.K., Huang, L.G., Wen, C.Q. Fu, Y.H., 2015. Studies on non-alkaloid constituents from Ochrosia elliptica. Chin. J. Chin. Mat. Med. 40, 1508-1513.

Macabeo, A.P.G., Lopez, A.D.A., Schmidt, S., Heilmann, J., Dahse, H.M., Alejandro, G.J.D., Franzblau, S.G., 2013. Antitubercular and cytoxic constituents from Goniothalamus gitingensis. Rac. Nat. Prod. 8:1, 41-45.

Macabeo, A.P.G., Rubio, P.Y.M., Higuchi, T., Umezawa, N., Federl, C., Budde, S., Bangcaya, P., Alejandro, G.J.D., 2017. Polyoxygenated seco-cyclohexenes and other constituents from Uvaria valderramensis. Biochem. Syst. Ecol. 71, 200-204.

Macabeo, A.P.G., Letada, A.G., Budde, S., Faderl, C., Dahse, H.M., Franzblau, S.G., Alejandro, G.J.D., Pierens, G.K., Garson, M.J., 2017. Antitubercular and cytotoxic chlorinated seco-cyclohexenes from Uvaria alba. J. Nat. Prod. 80, 3319-3323.

Meesakul, P., Pudhom, K., Pyne, S.G., Laphookhieo, S., 2017. Hydride flavanflavanones from Friesodielsia desmodies and their inhibitory activities against nitric oxide production. RSC Adv. 7, 17545-17550.

Melot, A., Fall, D., Gleye, C., Champy, P., 2009. Apolar Annonaceae acetogenins from the fruit pulp of Annona murucata. Molecules 14, 4387-4395. 
Meng, D.H., Xu, Y.P., Chen, W.L., Zou, J., Lou, L.G., Zhao, W.M., 2007. Anti-tumor clerodane-type diterpenes from Mitrephora thorelii. J. Asian Nat. Prod. Res. 9, 679-684.

Ming, H., Jinghua, Z., Changqi, H., 2001. Studies on the chemical components of Clematis chinensis. J. Chin. Pharm. Sci. 10, 180-182.

Moghadamtousi, S.Z., Fadaeinasab, M., Nikzad, S., Mohan, G., Ali, H.M., Kadir, H.A., 2015. Annona muricata (Annonaceae): A review of its traditional uses, isolated acetogenins and biological activities. Int. J. Mol. Sci. 16, $15625-15658$.

Moharam, B.A., Jantan, I., Jalil, I., Ahmad, F., 2012. Inhibitory effect of compounds from Goniothalamus tapis Miq. and Goniothalamus uvaroides king on platelet-activating factor receptor binding. Phyother. Res. 26, 687-691.

Nakasone, Y., Takara, K., Wada, K., Tanaka, J., Yogi, S., Nakatani, N., 1996. Antioxidative compounds isolated from kakuto, non-centrifural cane sugar. Biosci. Biotec. Biochem. 60, 1714-1716.

Nantapap, S., Sangrueng, K., Nuntasaen, N., Meepowpan, P., Pompimon, W., 2015. Chemical constituents from aerial parts of Polyalthia evecta (Pierre) Finet \& Gagnep. Var. attopeuensis.Int. J. Chem. Sci. 13, 1705-1712.

Nurunajah, G., Ahmat, N., Hadiani, I.N., Ishak, Z., 2011. Flavonoid constituents from the stem bark of Polyalthia cauliflora var. cauliflora. Aust. J. Basic Appl. Sci. $5,154-158$.

Nyandoro, S.S., Munissi, J.J., Gruhonjic, A., Duffy, S., Pan, F., Puttreddy, R., Holleran, J.P., Fitzpatrick, P.A., Pelletier, J., Avery, V.M., Rissanen, K., Erdélyi, M., 2017. Polyoxygenated cyclohexenes and other constituents of Cleistochlamys kirkii leaves. J. Nat. Prod. 80, 114-125.

Ortega, A.R., Toscano, R.A., Barragán, A.H., Cisneros, C.A., Nathan, P.J., 2015. Strucutre elucidation of a new isoflavone by exclusive use of ${ }^{1} \mathrm{H}$ NMR measurements. Magn. Reson. Chem. 53, 860-865.

Pancharoen, O., Athipornchai, A., Panthong, A., Taylor, W.C., 2008. Isoflavone and rotenoids from the leaves of Millettia brandisiana. Chem. Pharm. Bull. 56, 835-838.

Popsavin, V., Kavačević, I., Benedeković, G., Popsavin, M., Kojoć, V., Bogdanović., 2012. Divergent synthsis of cytotoxic styryl lactones related to goniobutenolides A and B, and to crassalactone D. Org. Lett. 14, 5956-5959.

Prachyawarakorn, V., Sangpetsiripan, S., Surawatanawong, P., Mahidol, C., Ruchirawat, S., Kittakoop, P., 2013. Flavans from Desmos chochinchinensis as potent aromatase inhibitors. Med. Chem. Commun. 4, 1590-1596.

Prawat, U., Chaimanee, S., Butsuri, A., Salae, A.W., Tuntiwachwuttikul, P., 2012. Bioactive styryllactones, two new naphthoquinones and one new styryllactones, and other constituents from Goniothalamus scortechinii. Phytochem. Lett. 5, 529-534. 
Prawat, U., Chairerk, O., Phupornprasert, U., Salae, A.W., Tuntiwachwuttikul, P., 2013. Two new C-benzylated dihydrochalcone derivatives from the leaves of Melodorum siamensis. Planta. Med. 79, 83-86.

Prawat, U., Phupornprasert, D., Butsuri, A., Salae, A.W., Boonsri, S., Tuntiwachwuttikul, P., 2012. Flavonoids from Friesodielsia discolor. Phytochem. Lett. 5, 809-813.

Promchai, T., Jaidee, A., Cheenpracha, S., Trisuwas, K., Rattanajak, R., Kamchonwongpaisan, S., Laphookhieo, S., Pyne, S.G., Ritthiwigrom, T., 2016. Antimalarial oxoprotoberberine alkaloids from the leaves of Miliusa cuneate. J. Nat. Prod. 79, 978-983.

Promchai, T., Saesong, T., Ingkaninan, K., Laphookhieo, S., Pyne, S.G., Limtharakul, T., 2018. Acetylcholinesterase inhibitory activity of chemical constituents isolated from Miliusa thorelii. Phytochem. Lett. 23, 33-37.

Queiroz, E.F., Roblot, F., Laprévote, O., Paulo, M.Q., Hocquemiller, R., 2003. Two unusual acetogenins from the roots of Annona salzmanii. J. Nat. Prod. 66, $755-758$.

Quisumbing, E., 1951. Medicinal plants of the Philippines. Manila, Philippines.

Rahman, A., Katayama, T., Suzuki, T., Nakagawa, T., 2007. Stereochemistry and biosynthesis of (+)-lyoniresinol, a syringyl tetrahydronaphthalene lignan in Lyonia ovalifolia var. elliptical I: isolation and stereochemistry of syringyl lignans and predicted precursors to (+)-lyoniresinol from wood. J. Wood. Sci. 53, 161-167.

Rittiwong, T., Mutarapat, T., Ponglimanont, C., Mahabusarakam, W., Chakthong, S., 2011. Saiyutones A-D: four new unusual biflavones from Desmos chinensis. Tetrahedron 67, 5444-5449.

Rukachaisirikul, V., Khamthong, N., Sukpondma, Y., Phongpaichit, S., Towatana, N.H., Graidist, P., Sakayaroj, J., Kirtikara, K., 2010. Cyclohexene diketopiperazine, lactone and phenol derivatives from the sea fan-derived fungi Nigrospors sp. PSU-F11 and PSU-F12. Arch. Pharm. Res. 33, 375-380.

Sampath, M., Vasanthi, M., 2013. Isolation, structural elucidation of flavonoids from Polyalthia longifolia (SONN.) thawaites and evaluation of antibacterial, antioxidant and anticancer potential. Int. J. Pharm. Pharm. Sci. 5, 336-341.

Salum, M.L., Robles, C.J., Erra-Balsells, R., 2010. Photoisomerization of ionic liquid ammonium cinnamates: one-pot synthesis-isolation of $Z$-cinnamic acids. 12 , 4808-4811.

Saripalli, H.R., Dixit, P.K., 2013. Studies on morphological features and biological activities of the genus annona of Ethiopia, N. E. Africa with a special emphasis on Graviola: A review. Int. J. Pharm. Sci. Res. 821-827.

Saunders, R.M.K., Chalermglin, P., 2008. A synopsis of Goniothalamus species (Annonaceae) in Thailand, with descriptions of three new species. Bot. J. Linn. Soc. 156, 355-384.

Sheldrick, G.M., 2015. SHELXT-integrated apace-group and crystal-structure determination. Acta Cryst. A71, 3-8 
Sheldrick, G.M., 2015. Crystal structure refinement with SHELXL. Acta Cryst. C71, 3-8.

Shing, T.K.M., Tsui, H.C., Zhou, Z.H., 1995. Enantiospecific syntheses of (+)goniofufurone, (+)-7-epi-goniofufurone, (+)-goniobutenolide A, (-)goniobutenolide B, (+)-goniopypyrone, (+)-altholactone, (+)-goniotriol, and (+)-7-acetylgoniotriol. J. Org. Chem. 60, 3121-3130.

Shing, T.K.M., Tai, V.W.F., Tsui, H.C., 1994. Goniobutenolides A and B; serendipitous syntheses, relative and absolute configuration. J. Chem. Soc. Chem. Commun. 1293-1294.

Si, W., Zhang, Y.J., Chen, R.Y., Yu, D.Q., 2002. Goniolactones A-F, six new styrylpyrone derivatives from the roots of Goniothalamus cheliensis. J. Nat. Prod. 65, 835-841.

Singh, O., Muthukrishnan, M., 2005. Synthesis of isoflavones containing naturally occurring substitution pattern by oxidative rearrangement of respective flavanones using thallium(III) p-tosylate. Indian J. Chem. 44B, 2575-2581.

Sriyatep, T., Andersen, R.J., Patrick, B.O., Pyne, S.G., Muanprasat, C., Seemakham, S., Borwornpinyo, S., Laphookhieo, S., 2017. Scalemic caged xanthones isolated from the stem bark extract of Garcinia propinqua. J. Nat. Prod. 80, $1658-1667$.

Starks, C.M., Williams, R.B., Rice, S.M., Norman, V.L., Lawrence, J.A., Goering, M.G., Johnson, M.O.N., Hu, J.F., Eldridge, G.R., 2012. Polyoxygenated cyclohexene derivatives from Monanthotaxis congoensis. Phytochemistry 74, 185-189.

Suchaichit, N., Kanokmedhakul, K., Panthama, N., Poopasit, K., Moosophon, P., Kanokmedhakul, S., 2015. A 2H-tetrahydropyran derivative and bioactive constituents from the bark of Goniothalamus elegants Ast. Fitoterapia 103, 206-212.

Sun, L., Zhao, R., Lan, X., Chen, R., Wang, S., Du, G., 2014. Goniolactone C, a styryl lactone derivative, inhibits PDGF-BB-induced vascular smooth muscle cell migration and proliferation via PDGFR/ERK signaling. Molecules 19, 1950119515.

Sun, S., Liu, J., Sun, X., Zhu, W., Yang, F., Felczak, L., Dou, Q.P., Zhou, K., 58. Novel Annonaceous acetogenins from Graviola (Annona muricata) fruits with strong anti-proliferative activity. Tetrahedron Lett. 58, 1895-1899.

Supudompol, B., Chaowasku, T., Kingfang, K., Burud, K., Wongseripipatana, S., Likhitwitayawuid, K., 2004. A new pimarane from Mitrephora tomentosa. Nat. Prod. Res. 18, 387-390.

Surivet, J.P., Vatèle, J.M., 1999. Total synthesis of antitumor Goniothalamus styryllactones. Tetrahedron 55, 13011-13028.

Tahara, S., Hashidoko, Y., Ingham, J.L., Mizutani, J., 1986. New 5-Omethylisoflavone in the roots of yellow lupin (Lupinus luteus L. cv. Barpine). Agric. Biol. Chem. 50, 1809-1819. 
Tip-pyang, S., Limpipatwattana, Y., Khumkratok, S., Siripong, P., Sichaem, J. 2010. A new cytotoxic 1-azaanthraquinone from the stems of G. laoticus. Fitoterapia 81, 894-896.

Tsubuki, M., Kanai, K., Nagase, H., Honda, T., 1999. Stereocontrolled syntheses of novel styryl lactones, (+)-goniodiol, (+)-goniotriol, (+)-8-acetylgoniotriol, (+)-goniofufurone, (+)-9-deoxygoniopypyrone, (+)-goniopypyrone, and (+)altholactone from common intermediates and cytotoxicity of their congeners. Tetrahedron 55, 2493-2514.

Tuntipaleepun, M., Chakthong, S., Ponglimanont, C., Plodpai, P., Voravuthikunchai, S.P., 2012. Antifungal and cytotoxic substances from the stem barks of Desmos chinensis. Chin. Chem. Lett. 23, 587-590.

Wagoner, R.M.V., Mantle, P.G., Wright, J.L.C., 2008. Biotsynthesis of scorinone, a 2-aaanthraquinone from Amorosia littoralis, a fungus from marin sediment. K. Nat. Prod. 71, 426-430.

Wang, S., Zhang, Y.J., Chen, R.Y., Yu, D.Q., 2002. Goniolactones A-F, six new styrylpyrone derivatives from the roots of Goniothalamus cheliensis. J. Nat. Prod. 65, 835-841.

Wang, S., Dai, S.J., Zhang, P.C., Chen, R.Y., Zeper, A., Yu, S.S., Yu, D.Q., 2003. Studies on the chemical constituents of the roots of Goniothalamus cheliensis and Uvaria macrophylla. Acta Chin. Sinica. 61, 1090-1096.

Waterman, P. G., Muhammad, I., 1985, Sesquiterpenes and alkaloids from Cleistopholis patens. Phytochemistry 24, 523-527.

Wu, M.D., Cheng, M.J., Chen, I.S., Su, Y.S., Hsieh, S.Y., Chang, H.S., Chang, C.W., Yuan, G.F., 2013. Phytochemistry investigation of Annulohypoxylon ilanense, an endophytic fungus derived from Cinnamomun species. Chem. Biodivers. 10, 493-505.

Wu, T.S., Chan, Y.Y., Leu, Y.L., 2000. The constituents of the root and stem of Aristolochia cucurbitifolia Hayata and their biological activity. Chem. Pharm. Bull. 48, 1006-1009.

Wu, Y.C., Chang, F.R., Duh, C.Y., Wang, S.K., Wu, T.S., 1992. Cytotoxic Styrylpyrones of Goniothalamus amuyon. Phytochemistry 31, 2851-2853.

Xu, D.X., Sharpless, K.B., 1994. Synthesis and stereochemical assignments for goniobutenolides A and B. Tetrahedron Lett. 35, 4685-4688.

Yamauchi, S., Ichikawa, H., Nishiwaki, H., Shuto, Y., 2015. Evaluation of plant growth regulatory activity of furofuran lignan bearing a 7,9':7',9-diepoxy structure using optical pure (+)- and (-)-enantiomers. J. Agric. Food Chem. $63,5224-5228$.

Zdero, C., Bohlmann, F., King, R.M., Robinson, H., 1986. Diterpene glycosides and other constituents from Argentinian Baccharis species. Phytochemistry 12, 2841-2855.

Zhang, Y.J., Kong, M., Chen, R.Y., Yu, D.Q., 1999. Alkaloids from the roots of Goniothalamus griffithii. J. Nat. Prod. 62, 1050-1052.

Zhang, Y.J., Zhou, G.X., Chen, R.Y., Yu, D.Q., 1998. Styryllactones from the rhizomes of Goniothalamus griffithii. J. Asian Nat. Prod. Res. 1, 189-197. 
Zhou C.C., Lui, C.T., Huang, X.X., Wu, J., Li, L.Z., Li, D.M., Song, S.J., 2013. Isolation and identification of aromatic compounds from the leaves of Crataegus pinnatifida Bge. Chin. J. Med. Chem. 23, 213-217.

Zhou, Q., Fu, Y.H., Zhang, Y.Q., Wu, S.Y., Song, X.P., Cao, C.K., Xu, W., Chen, G.Y., 2016. Fissitungfines A and B, two novel aporphine related alkaloids from Fissistigma tungfangense. Tetrahedron Lett. 57, 4162-4164.

Zhou, Q., Fu, Y.H., Zhang, Y.Q., Wu, S.Y., Song, X.P., Cao, C.K., Xu, W., Chen, G.Y., 2018. Bioactive aporphine alkaloids from Fissistigma tungfangense. Phytochem. Lett. 25, 105-108.

Zhou W., Zhuang, Y., Bai, Y., Bi, H., Liu, T., Ma, Y., 2016. Biosynthesis of phlorisovalerophenone and 4-hydroxy-6-isobutyl-2-pyrone in Escherichia coli from glucose. Microb. Cell Fact. 15, 149.

Zhu, J.X., Yu, D.L., Huang, W.H., Sun, L., Lv, Y., Zheng, Q.T., Lee, K.H., Yu, J.G., 2012. Goniodilactone and gonioheptenolactone, two novel cytotoxic styryllactones from the leaves of Goniothalamus cheliensis. Chin. Chem. Lett. $23,583-586$. 


\section{Graphical abstract}

\section{Alkaloids and styryllactones from Goniothalamus cheliensis}

Wuttichai Jaidee, Raymond J. Andersen, Brian O. Patrick, Stephen G. Pyne, Chatchai Muanprasat, Suparerk Borwornpinyo, Surat Laphookhieo*

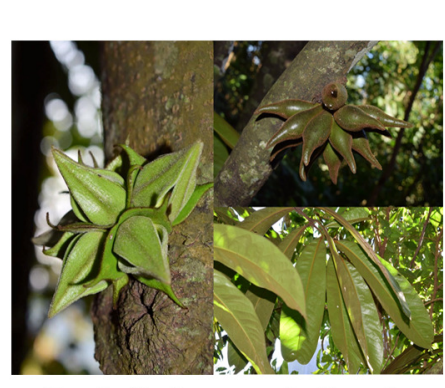

Goniothalamus cheliensis

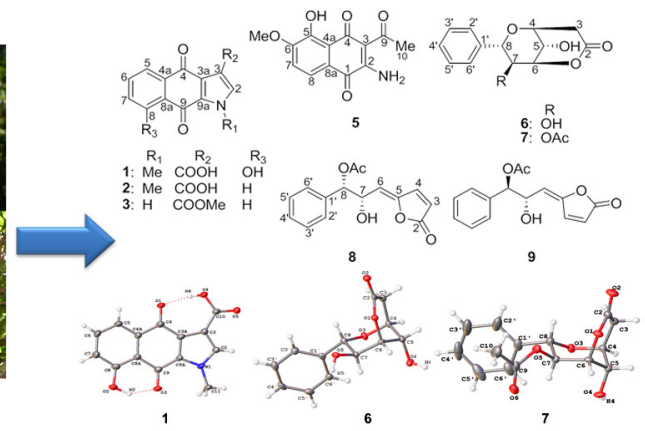

Eight previously undescribed compounds were isolated and characterized from Goniothalamus cheliensis. Griffithazanone A showed potent cytotoxicities against human colorectal cancer cells (HCT-116). 


\section{Figure legends}

Fig. 1. The structures of compounds from G. cheliensis twigs.

Fig. 2. The structures of compounds from G. cheliensis leaves.

Fig. 3. The key COSY and HMBC correlations of 1-3 and 5-9.

Fig.4. The key NOESY correlations of 6 and 7 (molecular structures generated using 3D structure ChemBioDraw Ultra 11.0).

Fig. 5. Single crystal X-ray structure of 1.

Fig. 6. Single crystal X-ray structure of 4.

Fig. 7. Single crystal X-ray structure of 6.

Fig. 8. Single crystal X-ray structure of 7.

Fig. 9. ECD spectra of 6 and 7.

Fig. 10. ECD spectra of 8-11.

Fig. 11. Plausible biosynthetic pathway of 1-4 (a) and 5 (b). 
(2)

$\begin{array}{lll}R_{1} & R_{2} & R_{3}\end{array}$

1: $\mathrm{Me} \mathrm{COOH} \mathrm{OH}$

2: $\mathrm{Me} \mathrm{COOH} \mathrm{H}$

3: $\mathrm{H}$ COOMe $\mathrm{H}$

4: $\mathrm{H} \mathrm{Me} H$<smiles>[R]C=C1C=CC(=O)O1</smiles>

9: $\mathrm{OAc} \mathrm{OH}$

10: $\mathrm{OH} \mathrm{OH}$<smiles>CC(=O)O[C@H](c1ccccc1)[C@H]1O[C@@H]2CC(=O)O[C@H]2[C@H]1O</smiles>

15

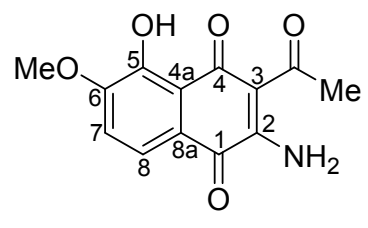

5<smiles>O=C1C=C/C(=C\[C@@H](O)[C@H](O)c2ccccc2)O1</smiles>

11<smiles>O=C1C=C[C@H]2O[C@@H](c3ccccc3)[C@H](O)[C@H]2O1</smiles>

16

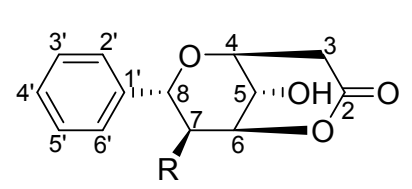

$R$

6: $\mathrm{OH}$

7: OAc<smiles>[R]C(c1ccccc1)[C@H]([R2])[C@H]1CC=CC(=O)O1</smiles>

$\begin{array}{ll}R_{1} & R_{2}\end{array}$

12: $\mathrm{OH} \mathrm{OH}$

13: $\mathrm{OAc} \mathrm{OH}$

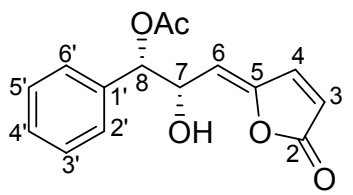

8<smiles>CC(=O)O[C@@H]([C@@H]1CC=CC(=O)O1)[C@H](O)c1ccccc1</smiles>

14<smiles>COc1cc([C@@H]2OC[C@H]3C(=O)OC[C@H]32)cc(OC)c1O</smiles>

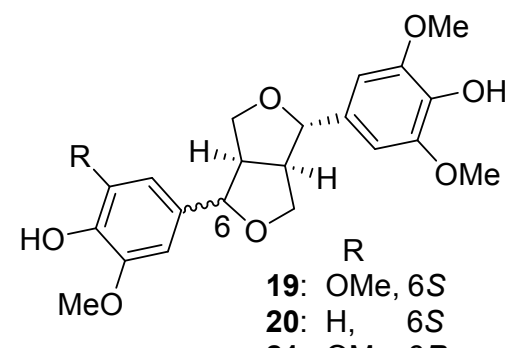<smiles>[R2]O[R10]([R2])([H])OC</smiles><smiles>C[C@H]1C2=C(NC(=O)C1O)C(=O)c1ccccc1C2=O</smiles>

25

23: $\mathrm{OMe} O \mathrm{OMe}, 6 S$

21: OMe, $6 R$<smiles>Cc1ccnc2c1C(=O)c1ccccc1C2=O</smiles><smiles>[R]c1cc(C(=O)O)cc([R])c1[R2]</smiles><smiles>[R]c1cc(C(=O)CC)cc([R])c1[R2]</smiles><smiles>O=Cc1ccc(O)cc1</smiles>

$\begin{array}{lll}R_{1} & R_{2} & R_{3}\end{array}$

27: $\mathrm{H} \mathrm{OH} \mathrm{OMe}$

$\mathrm{R}_{1} \quad \mathrm{R}_{2}$

$R_{2} \quad R_{3}$

30: $\mathrm{H} \quad \mathrm{OH}$ OMe

32<smiles>CCOC(=O)c1ccc(O)c(OC)c1</smiles>

28: $\mathrm{H}$ OH H

31: $\mathrm{OMe} \mathrm{OH} \mathrm{OMe}$

29: $\mathrm{H}$ Me $\mathrm{H}$<smiles>COc1cc(/C=C/C(=O)O)ccc1O</smiles>

34<smiles>COc1cccc2c1C(=O)O[C@H](C)C2</smiles>

35<smiles>COc1ccc2c(c1O)C(=O)C(N)=C(C(C)=O)C2=O</smiles>

45 (isolated from G. scortechinii)

Fig. 1. 
<smiles>COc1cc(OC)c2c(OC)c(-c3ccc4c(c3)OCO4)c(=O)oc2c1</smiles>

36<smiles>[R][R]=C1OCOc2ccc(-c3coc4cc([R])cc([R])c4c3=O)cc21</smiles>

$$
\text { 37: } \mathrm{OH} \quad \mathrm{OMe}
$$$$
\text { 38: } \mathrm{OMe} \mathrm{OMe}
$$<smiles>COc1c2c(cc3occ(-c4ccc5c(c4)OCO5)c(=O)c13)OC(C)(C)C=C2</smiles>

39

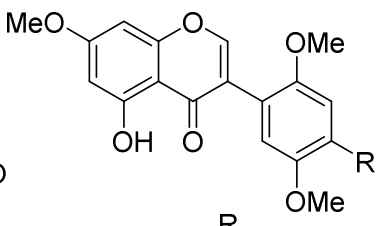

40: $\mathrm{OH}$

41: $\mathrm{OMe}$<smiles></smiles>

Fig. 2.

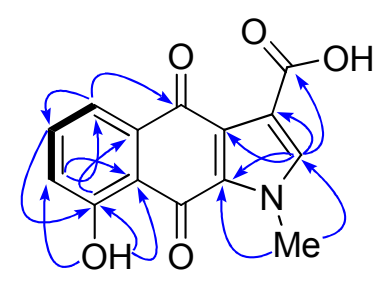

1
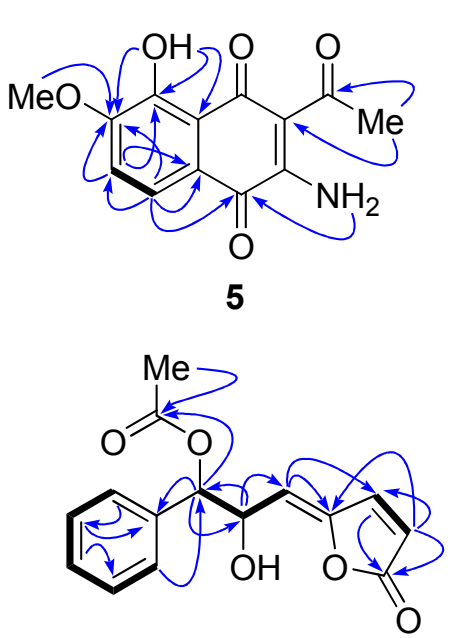

8

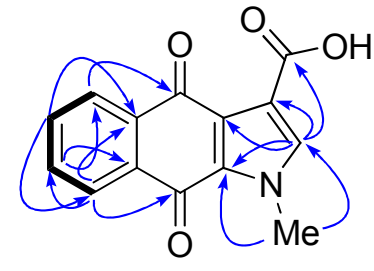

2

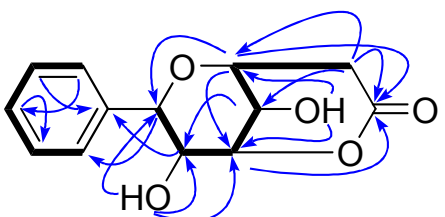

6

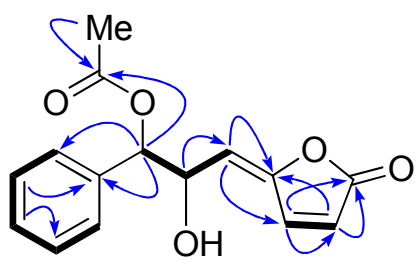

9

${ }^{1} \mathrm{H}-{ }^{1} \mathrm{H}$ COSY $: \mathrm{H}-\mathrm{H} \quad \mathrm{HMBC}: \mathrm{H} \cap \mathrm{C}$

Fig. 3. 

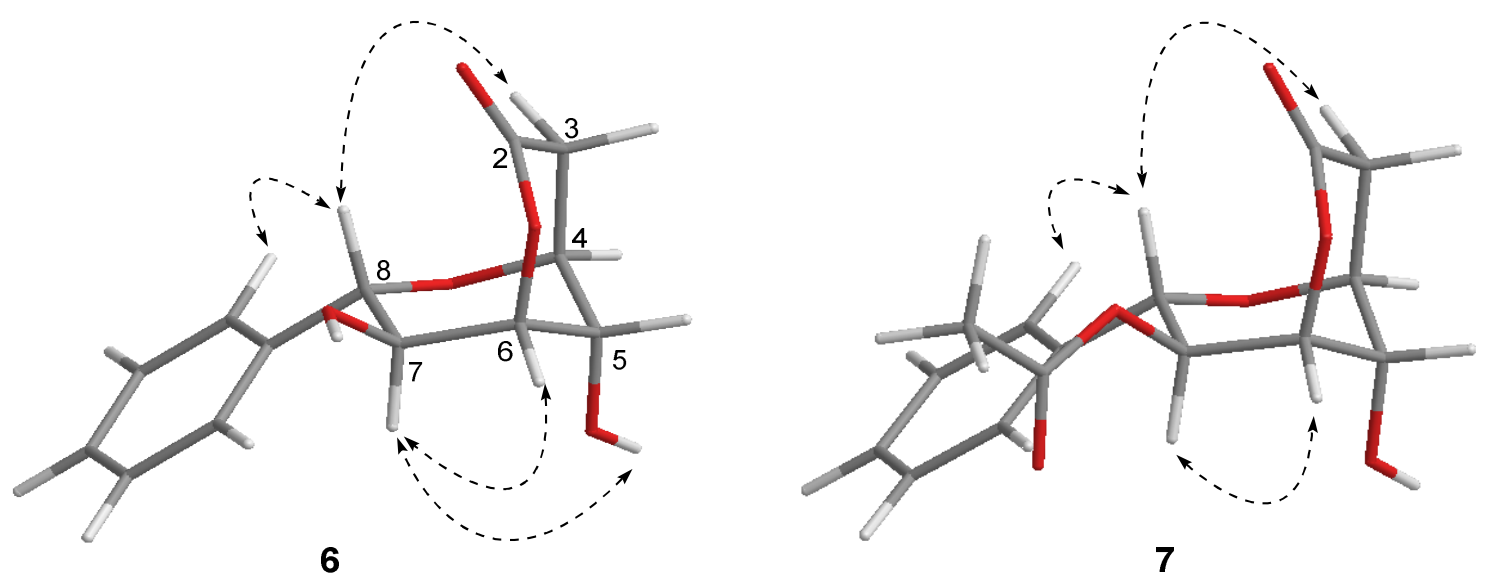

Fig.4.

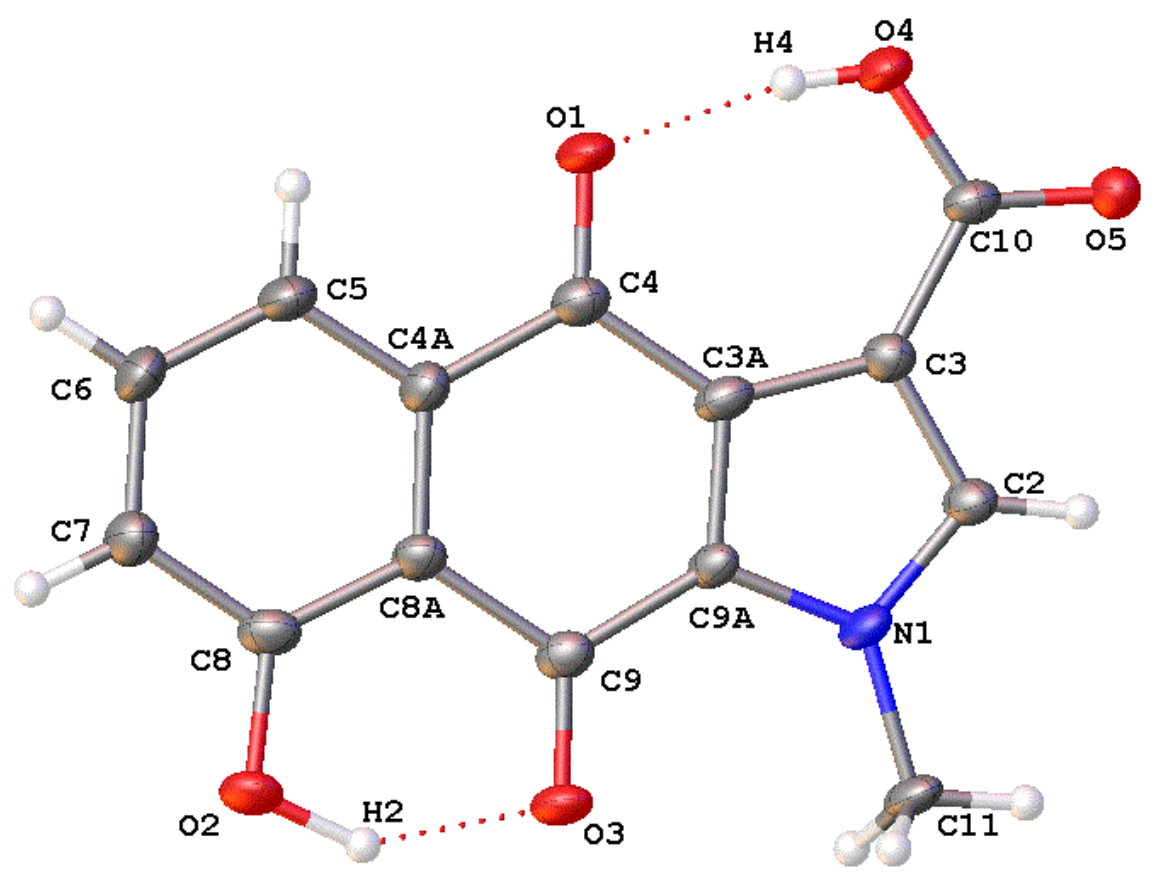

Fig. 5. 


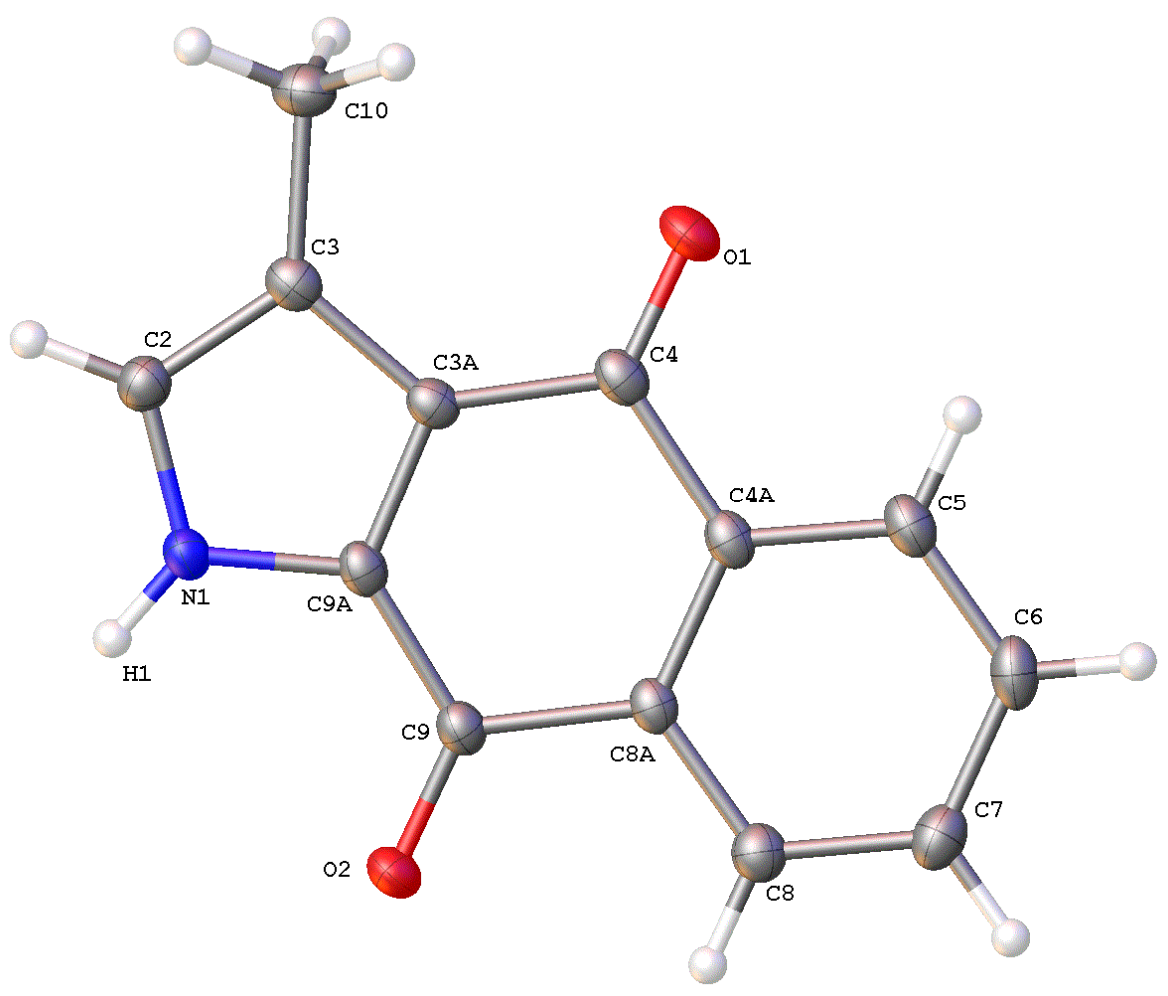

Fig. 6.

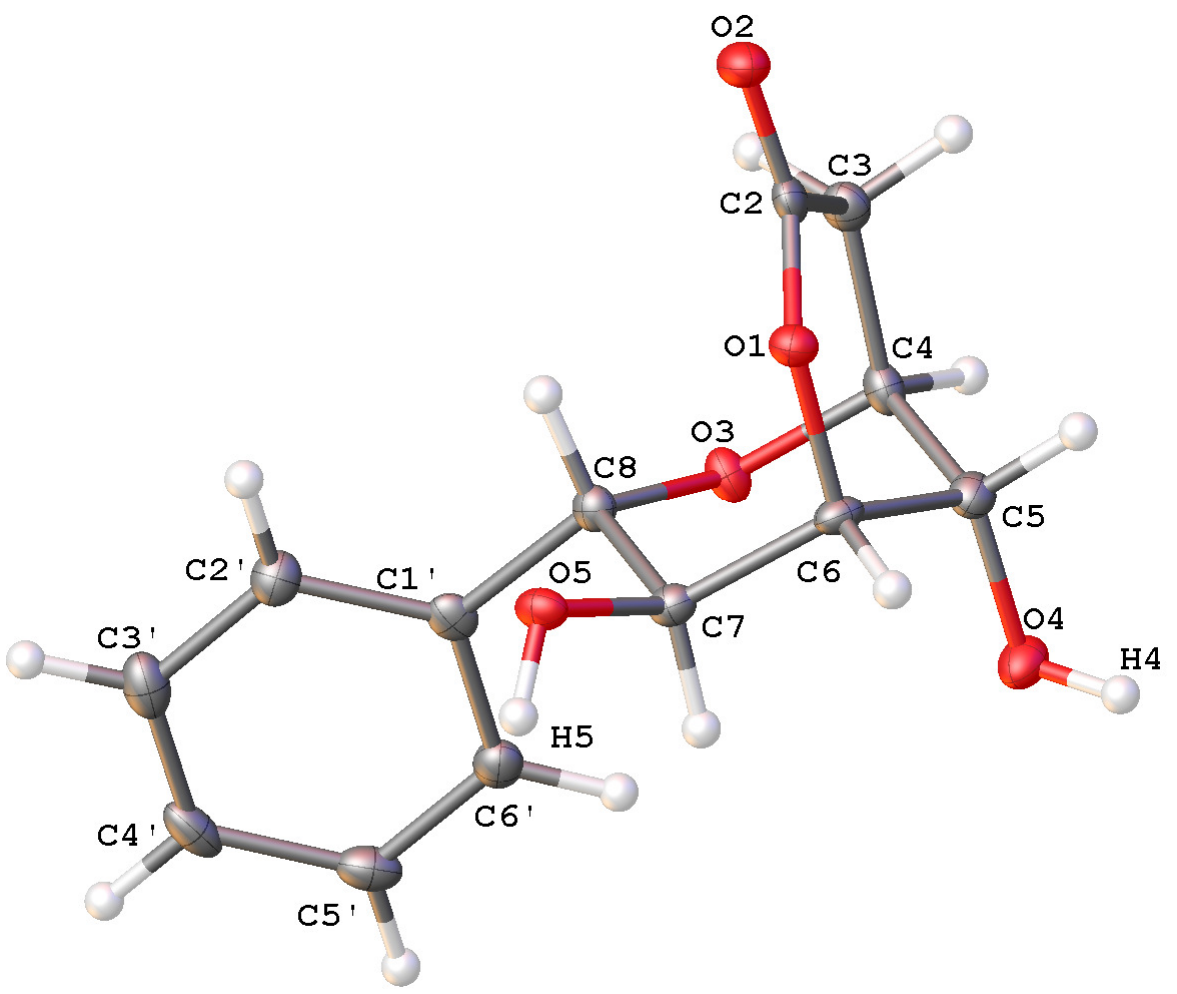

Fig. 7. 


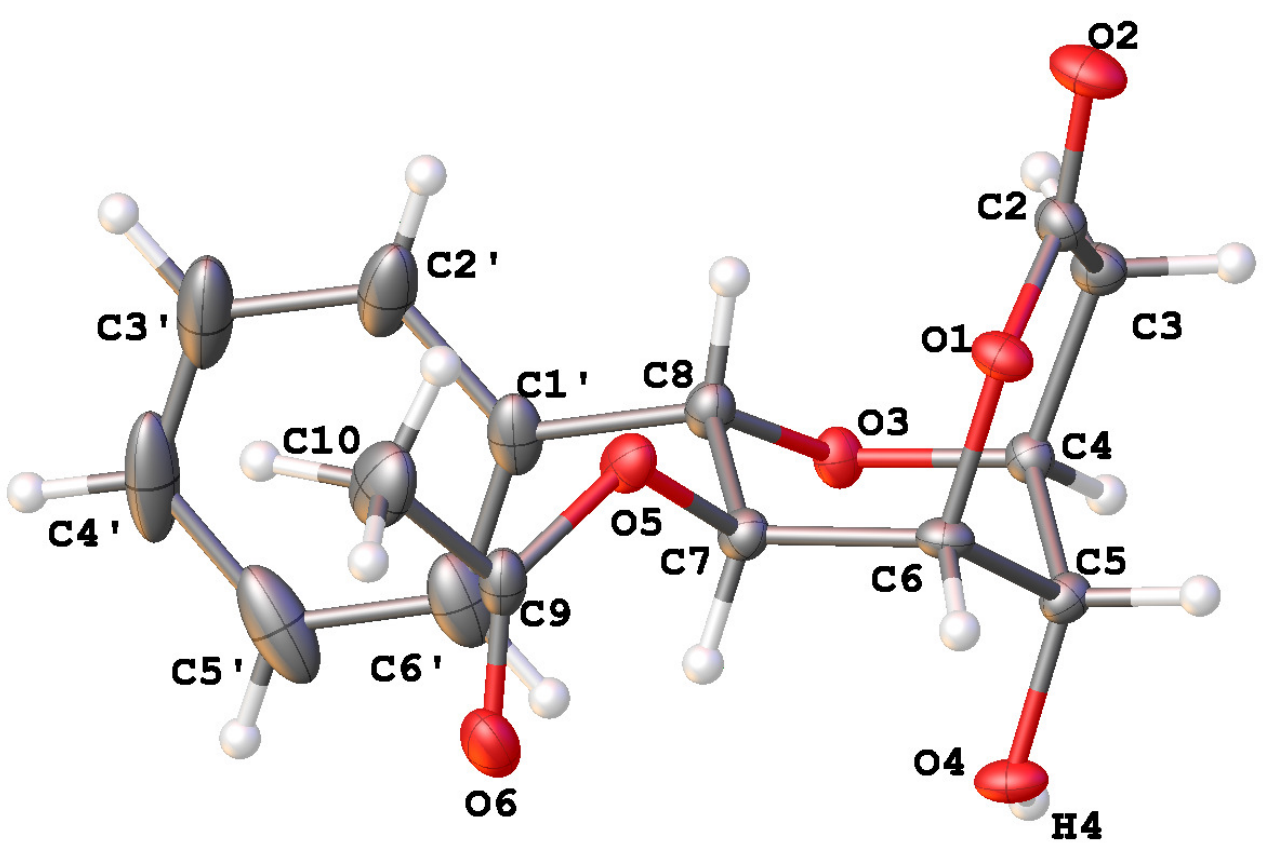

Fig. 8 .

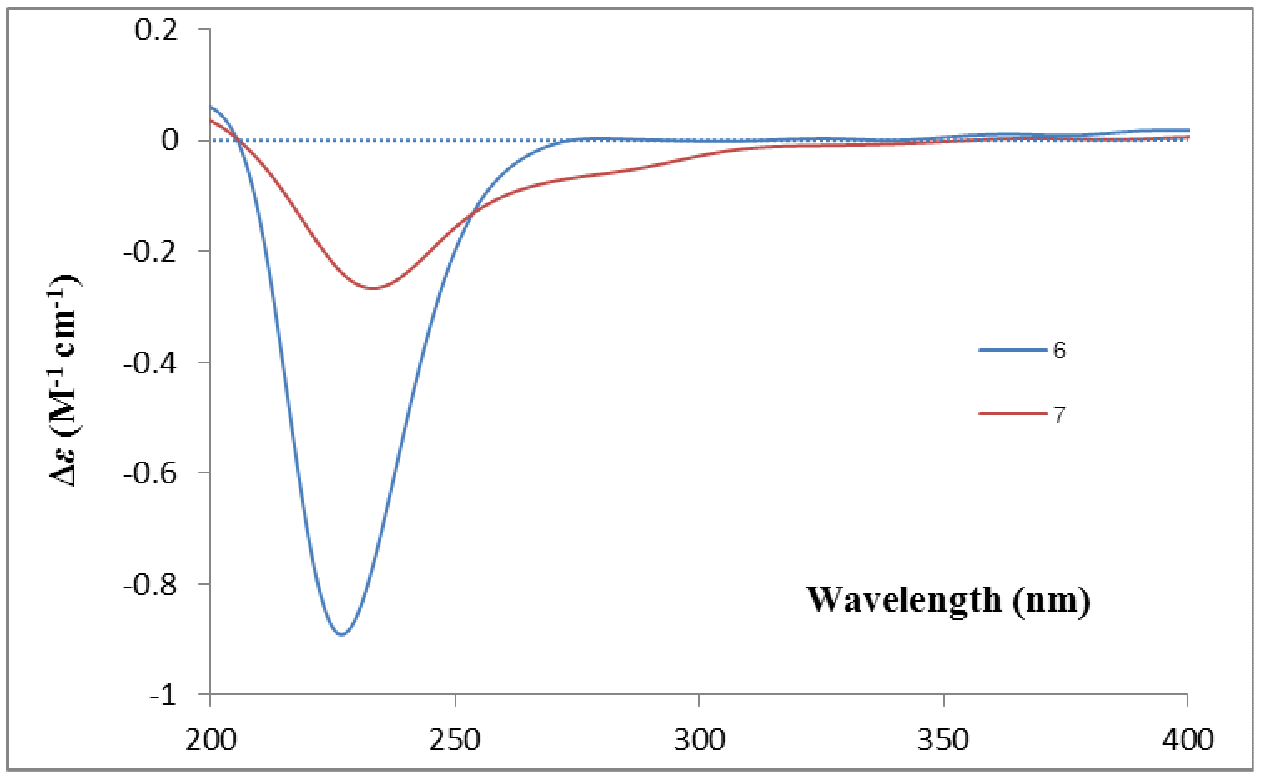

Fig. 9. 


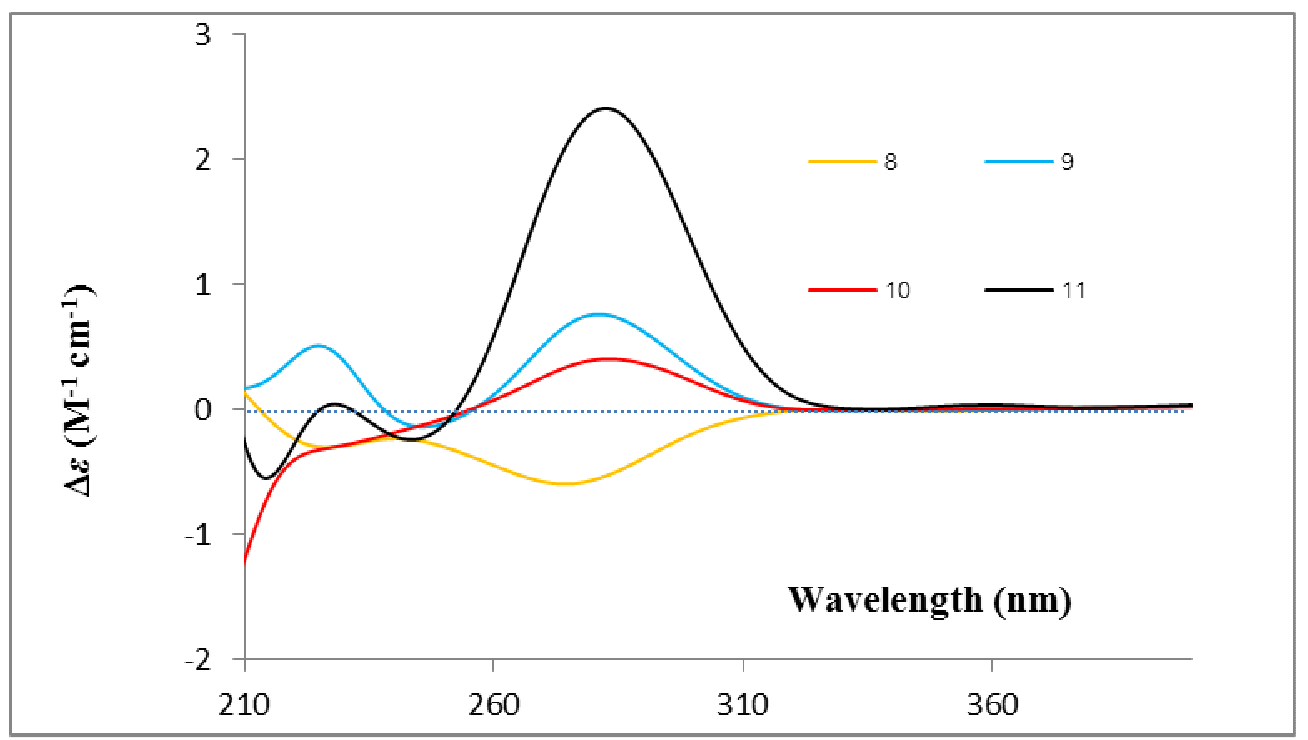

Fig. 10. 
acetyl-CoA

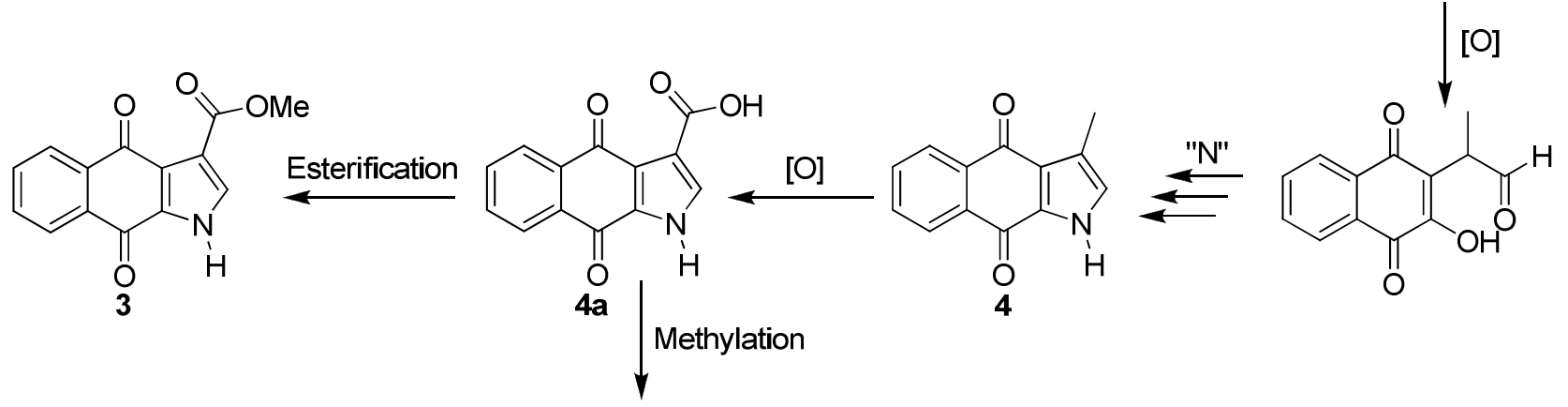<smiles>[2H]c1cc(C(=O)O)c(C(=O)O)c2c1-c1ccccc1C2=O</smiles>

b.

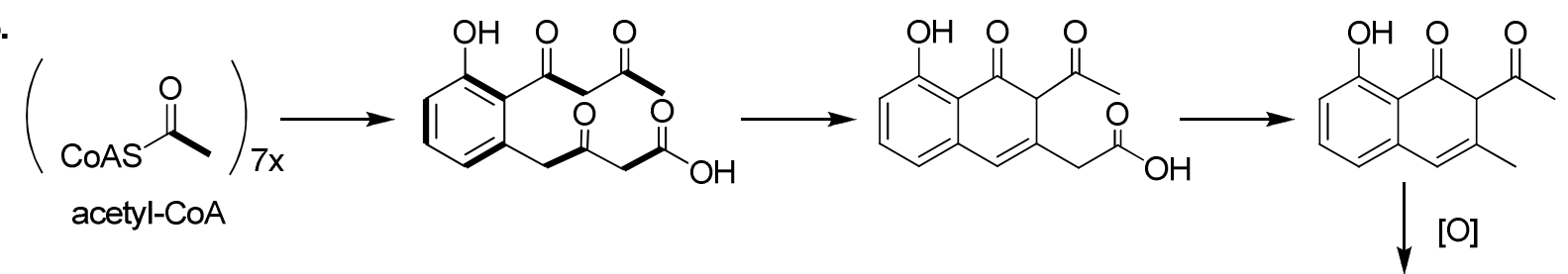

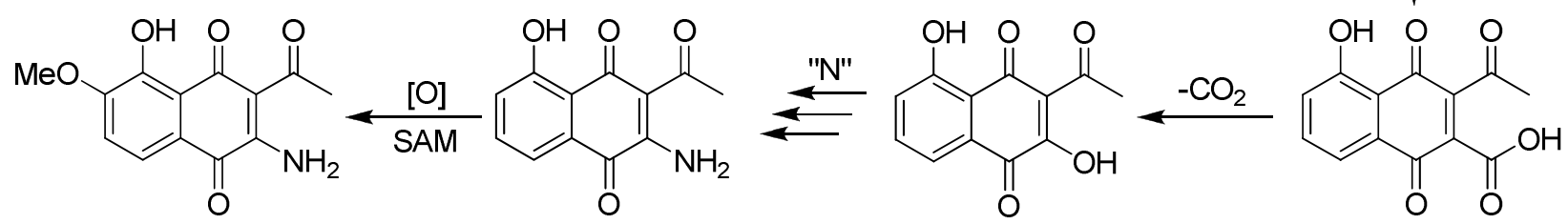

Fig. 11. 
Table 1

${ }^{1} \mathrm{H}(600 \mathrm{MHz})$ and ${ }^{13} \mathrm{C}(150 \mathrm{MHz}) \mathrm{NMR}$ Spectroscopic data of 1-3.

\begin{tabular}{|c|c|c|c|c|c|c|}
\hline \multirow[b]{2}{*}{ position } & \multicolumn{2}{|l|}{$1\left(\mathrm{CDCl}_{3}\right)$} & \multicolumn{2}{|l|}{$2\left(\mathrm{CDCl}_{3}\right)$} & \multicolumn{2}{|c|}{3 (methanol- $\left.d_{4}\right)$} \\
\hline & $\delta_{\mathrm{C}}$, type & $\delta_{\mathrm{H}}(J$ in $\mathrm{Hz})$ & $\delta_{\mathrm{C}}$, type & $\delta_{\mathrm{H}}(J$ in $\mathrm{Hz})$ & $\delta_{\mathrm{C}}$, type & $\delta_{\mathrm{H}}(J$ in $\mathrm{Hz})$ \\
\hline 2 & $138.0, \mathrm{CH}$ & $7.74, \mathrm{~s}$ & $137.5, \mathrm{CH}$ & $7.73, \mathrm{~s}$ & $130.2, \mathrm{CH}$ & $7.81, \mathrm{~s}$ \\
\hline 3 & $114.5, \mathrm{C}$ & & $116.4, \mathrm{C}$ & & $115.2, \mathrm{C}$ & \\
\hline $3 a$ & $123.5, \mathrm{C}$ & & $123.1, \mathrm{C}$ & & $124.0, \mathrm{C}$ & \\
\hline 4 & $183.1, \mathrm{C}$ & & $184.0, \mathrm{C}$ & & $179.1, \mathrm{C}$ & \\
\hline $4 \mathrm{a}$ & $132.0, \mathrm{C}$ & & $132.6, \mathrm{C}$ & & 133.7, C & \\
\hline 5 & $120.7, \mathrm{CH}$ & $7.82, \mathrm{~d}(7.4)$ & $127.4, \mathrm{CH}$ & $8.26, \mathrm{dd}(7.4,1.3)$ & $124.0, \mathrm{CH}$ & $8.14, \mathrm{dd}(7.8,1.2)$ \\
\hline 6 & $136.0, \mathrm{CH}$ & $7.64, \mathrm{dd}(7.8,7.4)$ & 134.5, CH & $7.79, \operatorname{td}(7.5,1.5)$ & $132.1, \mathrm{CH}$ & $7.78, \mathrm{dd}(7.2,1.2)$ \\
\hline 7 & $126.1, \mathrm{CH}$ & $7.32, \mathrm{~d}(7.8)$ & 133.6, CH & $7.81, \mathrm{td}(7.5,1.5)$ & $131.4, \mathrm{CH}$ & 7.77 , ddd $(7.8,7.2,1.2)$ \\
\hline 8 & $162.5, \mathrm{C}$ & & $126.6, \mathrm{CH}$ & 8.21, dd $(7.4,1.3)$ & $125.2, \mathrm{CH}$ & 8.19 , dd $(7.8,1.2)$ \\
\hline $8 \mathrm{a}$ & $114.5, \mathrm{C}$ & & $132.6, \mathrm{C}$ & & $133.0, \mathrm{C}$ & \\
\hline 9 & $180.9, \mathrm{C}$ & & $175.5, \mathrm{C}$ & & 175.3, C & \\
\hline $9 \mathrm{a}$ & $130.9, \mathrm{C}$ & & $131.8, \mathrm{C}$ & & $134.4, \mathrm{C}$ & \\
\hline 10 & $161.5, \mathrm{C}$ & & $162.1, \mathrm{C}$ & & $163.2, \mathrm{C}$ & \\
\hline$N$-Me & $37.5, \mathrm{CH}_{3}$ & $4.15, \mathrm{~s}$ & $37.3, \mathrm{CH}_{3}$ & $4.16, \mathrm{~s}$ & & \\
\hline 8-OH & & $12.20, \mathrm{~s}$ & & & & \\
\hline $3-\mathrm{CO}_{2} \mathrm{Me}$ & & & & & $49.3, \mathrm{CH}_{3}$ & $3.89, \mathrm{~s}$ \\
\hline 3-COOH & & $13.68, \mathrm{~s}$ & & $13.70, \mathrm{~s}$ & & \\
\hline
\end{tabular}


Table 2

${ }^{1} \mathrm{H}(600 \mathrm{MHz})$ and ${ }^{13} \mathrm{C}(150 \mathrm{MHz})$ NMR Spectroscopic data of 5 and goniothalaminone B.

\begin{tabular}{|c|c|c|c|c|c|c|}
\hline \multirow[b]{2}{*}{ position } & \multicolumn{2}{|c|}{$5\left(\mathrm{DMSO}-d_{6}\right)$} & \multicolumn{2}{|l|}{$5\left(\mathrm{CDCl}_{3}\right)$} & \multicolumn{2}{|c|}{ goniothalaminone $\mathrm{B}\left(\mathrm{CDCl}_{3}\right)$} \\
\hline & $\delta_{\mathrm{C}}$, type & $\delta_{\mathrm{H}}(J$ in $\mathrm{Hz})$ & $\delta_{\mathrm{C}}$, type & $\delta_{\mathrm{H}}(J$ in $\mathrm{Hz})$ & $\delta_{\mathrm{C}}$, type & $\delta_{\mathrm{H}}(J$ in $\mathrm{Hz})$ \\
\hline 1 & $178.1, \mathrm{C}$ & & $178.0, \mathrm{C}$ & & $180.2, \mathrm{C}$ & \\
\hline 2 & $107.5, \mathrm{C}$ & & $106.9, \mathrm{C}$ & & $109.4, \mathrm{C}$ & \\
\hline 3 & $155.0, \mathrm{C}$ & & $158.4, \mathrm{C}$ & & $152.5, \mathrm{C}$ & \\
\hline 4 & $187.7, \mathrm{C}$ & & 186.3, C & & $185.5, \mathrm{C}$ & \\
\hline $4 \mathrm{a}$ & $114.3, \mathrm{C}$ & & $113.4, \mathrm{C}$ & & $114.0, \mathrm{C}$ & \\
\hline 5 & $151.6, \mathrm{C}$ & & $151.8, \mathrm{C}$ & & $152.0, \mathrm{C}$ & \\
\hline 6 & $155.8, \mathrm{C}$ & & $155.8, \mathrm{C}$ & & $152.1, \mathrm{C}$ & \\
\hline 7 & 114.7, CH & $7.29, \mathrm{~d}(8.4)$ & $113.2, \mathrm{CH}$ & $7.05, \mathrm{~d}(8.4)$ & $117.8, \mathrm{C}$ & $7.22, \mathrm{~d}(8.4)$ \\
\hline 8 & $120.7, \mathrm{CH}$ & $7.62, \mathrm{~d}(8.4)$ & $121.0, \mathrm{CH}$ & $7.75, \mathrm{~d}(8.4)$ & $120.7, \mathrm{C}$ & $7.76, \mathrm{~d}(8.4)$ \\
\hline $8 \mathrm{a}$ & $121.8, \mathrm{C}$ & & $126.7, \mathrm{CH}$ & & $125.0, \mathrm{C}$ & \\
\hline $5-\mathrm{OH}$ & & $13.94, \mathrm{~s}$ & & $13.97, \mathrm{~s}$ & & $11.71, \mathrm{~s}$ \\
\hline 6-OMe & $56.2, \mathrm{CH}_{3}$ & $3.91, \mathrm{~s}$ & $56.0, \mathrm{CH}_{3}$ & $4.02, \mathrm{~s}$ & $56.4, \mathrm{CH}_{3}$ & $3.99, \mathrm{~s}$ \\
\hline $\mathrm{NH}_{2}$ & & 9.12 , br s & & & & 7.07, br s \\
\hline & & 10.68, br s & & & & 10.66 , br s \\
\hline$C O \mathrm{Me}$ & $199.9, \mathrm{C}$ & & $200.7, \mathrm{C}$ & & $202.4, \mathrm{C}$ & \\
\hline $\mathrm{COMe}$ & $33.2, \mathrm{CH}_{3}$ & $2.56, \mathrm{~s}$ & $33.0, \mathrm{CH}_{3}$ & $2.73, \mathrm{~s}$ & $33.2, \mathrm{CH}_{3}$ & $2.73, \mathrm{~s}$ \\
\hline
\end{tabular}

Table 3

${ }^{1} \mathrm{H}(600 \mathrm{MHz})$ and ${ }^{13} \mathrm{C}(150 \mathrm{MHz})$ NMR Spectroscopic data of $\mathbf{6}$ and 7.

\begin{tabular}{|c|c|c|c|c|}
\hline \multirow[b]{2}{*}{ position } & \multicolumn{2}{|c|}{$6\left(\right.$ DMSO- $\left.d_{6}\right)$} & \multicolumn{2}{|l|}{$7\left(\mathrm{CDCl}_{3}\right)$} \\
\hline & $\delta_{\mathrm{C}}$, type & $\delta_{\mathrm{H}}(J$ in Hz $)$ & $\delta_{\mathrm{C}}$, type & $\delta_{\mathrm{H}}(J$ in Hz $)$ \\
\hline 2 & $168.7, \mathrm{C}$ & & $167.0, \mathrm{C}$ & \\
\hline $3_{\mathrm{ax}}$ & $35.2, \mathrm{CH}_{2}$ & 2.78, d (19.3) & $34.6, \mathrm{CH}_{2}$ & 3.15 , dd $(19.6,1.2)$ \\
\hline $3_{\text {eq }}$ & & $3.07, \mathrm{~d}(19.3,5.2)$ & & $3.02, \mathrm{dd}(19.6,5.2)$ \\
\hline 4 & $69.3, \mathrm{CH}$ & 4.07, d (4.6) & $69.7, \mathrm{CH}$ & $4.38, \mathrm{~m}$ \\
\hline 5 & $64.7, \mathrm{CH}$ & $4.15, \operatorname{td}(4.3,1.6)$ & $65.3, \mathrm{CH}$ & $4.33, \mathrm{dd}(4.6,1.6)$ \\
\hline 6 & $78.4, \mathrm{CH}$ & $4.45, \mathrm{~m}$ & $74.5, \mathrm{CH}$ & $4.91, \mathrm{dt}(4.6,2.6)$ \\
\hline 7 & $67.2, \mathrm{CH}$ & $3.87, \operatorname{ddd}(9.8,7.2,2.3)$ & $69.1, \mathrm{CH}$ & $5.37, \mathrm{dd}(10.3,2.6)$ \\
\hline 8 & $72.9, \mathrm{CH}$ & $4.24, \mathrm{~d}(9.8)$ & 70.6, CH & 4.67, d (10.3) \\
\hline $1^{\prime}$ & 139.7, C & & 136.0, C & \\
\hline $2^{\prime}$ & 128.7, CH & $7.38, d(7.9)$ & 126.7, CH & $7.41, \mathrm{~m}$ \\
\hline $3^{\prime}$ & 127.7, CH & 7.30,t (7.6) & 128.1, CH & $7.37, \mathrm{~m}$ \\
\hline $4^{\prime}$ & 127.6, CH & $7.26, \mathrm{t}(7.2)$ & 128.6, CH & $7.34, \mathrm{~m}$ \\
\hline $5^{\prime}$ & 127.7, CH & 7.30,t (7.6) & & $7.37, \mathrm{~m}$ \\
\hline $6^{\prime}$ & $128.7, \mathrm{CH}$ & $7.38, d(7.9)$ & & $7.41, \mathrm{~m}$ \\
\hline $5-\mathrm{OH}$ & & $5.70, d(4.0)$ & & \\
\hline 7-OH & & $5.16, \mathrm{~d}(6.9)$ & & \\
\hline 7-OCOMe & & & $169.1, \mathrm{C}$ & \\
\hline 7-OCOMe & & & $20.2, \mathrm{CH}_{3}$ & $1.94, \mathrm{~s}$ \\
\hline
\end{tabular}


Table 4

${ }^{1} \mathrm{H}(600 \mathrm{MHz})$ and ${ }^{13} \mathrm{C}(150 \mathrm{MHz})$ NMR Spectroscopic data of 8 and 9.

\begin{tabular}{|c|c|c|c|c|}
\hline \multirow[b]{2}{*}{ position } & \multicolumn{2}{|c|}{8 (acetone- $d_{6}$ ) } & \multicolumn{2}{|l|}{$9\left(\mathrm{CDCl}_{3}\right)$} \\
\hline & $\delta_{\mathrm{C}}$, type & $\delta_{\mathrm{H}}(J$ in $\mathrm{Hz})$ & $\delta_{\mathrm{C}}$, type & $\delta_{\mathrm{H}}(J$ in $\mathrm{Hz})$ \\
\hline 2 & $168.2, \mathrm{C}$ & & $169.6, \mathrm{C}$ & \\
\hline 3 & 119.6, CH & $6.31, \mathrm{~d}(5.5)$ & $121.2, \mathrm{CH}$ & $6.19, \mathrm{dd}(5.6,1.5)$ \\
\hline 4 & 114.0, CH & $7.74, \mathrm{~d}(5.5)$ & $139.6, \mathrm{CH}$ & $7.50, \mathrm{~d},(5.6)$ \\
\hline 5 & $149.8, \mathrm{C}$ & & $152.4, \mathrm{C}$ & \\
\hline 6 & $112.9, \mathrm{CH}$ & $5.46, \mathrm{~d}(9.2)$ & 107.0, CH & $5.82, \mathrm{dd}(10.0,1.5)$ \\
\hline 7 & $67.8, \mathrm{CH}$ & 4.98 , dd $(9.2,5.3)$ & $72.3, \mathrm{CH}$ & $5.69, \mathrm{dd}(10.0,4.2)$ \\
\hline 8 & $76.5, \mathrm{CH}$ & $5.85, \mathrm{~d}(5.3)$ & $74.8, \mathrm{CH}$ & $5.06, \mathrm{~d}(4.2)$ \\
\hline $1^{\prime}$ & $135.8, \mathrm{C}$ & & $137.4, \mathrm{C}$ & \\
\hline $2^{\prime}$ & 126.7, $\mathrm{CH}$ & $7.40, \mathrm{~d}(7.4)$ & $125.9, \mathrm{CH}$ & \\
\hline $3^{\prime}$ & $127.5, \mathrm{CH}$ & $7.33, \mathrm{t}(7.4)$ & $128.1, \mathrm{CH}$ & $734738 \mathrm{~m}$ \\
\hline $4^{\prime}$ & $127.3, \mathrm{CH}$ & $7.27, \mathrm{t}(7.3)$ & $128.8, \mathrm{CH}$ & $1.34-1.38, \mathrm{~m}$ \\
\hline $5^{\prime}$ & 127.5, CH & $7.33, \mathrm{t}(7.4)$ & $128.1, \mathrm{CH}$ & \\
\hline $6^{\prime}$ & 126.7, $\mathrm{CH}$ & $7.40, \mathrm{~d}(7.4)$ & $125.9, \mathrm{CH}$ & \\
\hline 8-OCOMe & 168.0, C & & $168.2, \mathrm{C}$ & \\
\hline 8-OCOMe & $19.5, \mathrm{CH}_{3}$ & 2.00, overlapped & $21.0, \mathrm{CH}_{3}$ & $2.07, \mathrm{~s}$ \\
\hline
\end{tabular}

